\title{
Jurassic (Bathonian and Callovian) Ammonites in Eastern Oregon and Western Idaho
}

GEOLOGICAL SURVEY PROFESSIONAL PAPER 1142

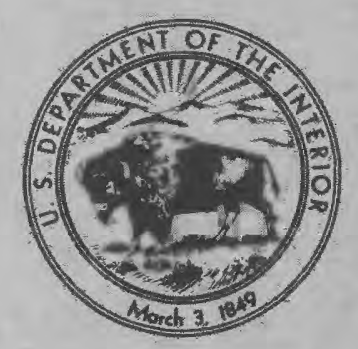





\section{Jurassic (Bathonian and Callovian) Ammonites in Eastern Oregon and Western Idaho}

By RALPH W. IMLAY

GEOLOGICAL SURVEY PROFESSIONAL PAPER 1142

The late Bathonian to middle Callovian ammonite succession in eastern Oregon is

remarkably similar to that in southern Alaska

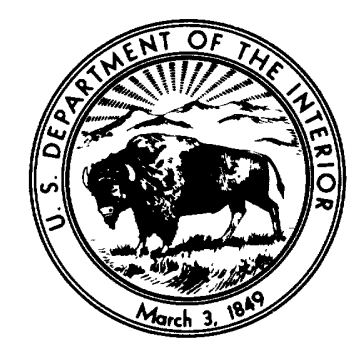

UNITED STATES GOVERNMENT PRINTING OFFICE, WASHINGTON : 1981 


\section{UNITED STATES DEPARTMENT OF THE INTERIOR \\ CECIL D. ANDRUS, Secretary}

\section{GEOLOGICAL SURVEY}

H. William Menard, Director

\section{Library of Congress Cataloging in Publication Data}

Imlay, Ralph Willard, 1908-

Jurassic (Bathonian and Callovian) ammonites in eastern Oregon and western Idaho.

(Geological Survey professional paper; 1142)

Bibliography: $p$.

Includes index.

1. Ammonoidea. 2. Paleontology - Jurassic. 3. Paleontology-Oregon. 4. Paleontology-Idaho. I. Title. II. Series: United States. Geological Survey. Professional paper; 1142.

QE807.A5159 564'.53 79-13537.

For sale by the Superintendent of Documents, U.S. Government Printing Office

Washington, D.C. 20402 


\section{CONTENTS}

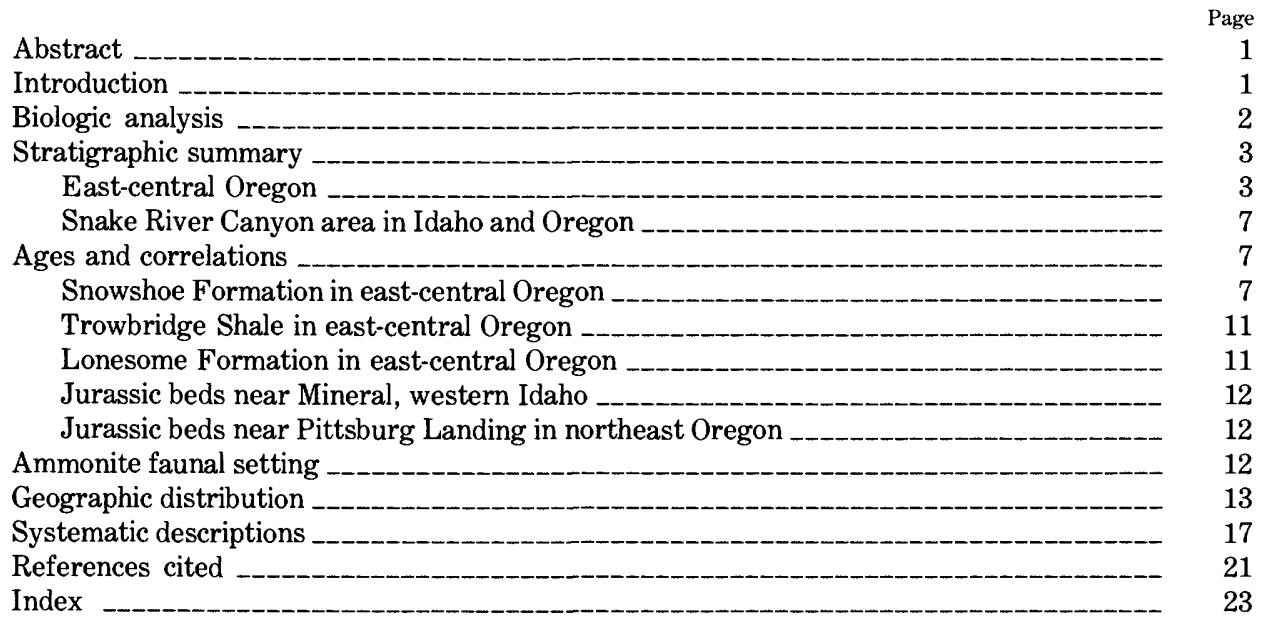

\section{ILLUSTRATIONS}

[Plates follow index]

Plate 1. Parapatoceras, Bullatimorphites, Xenocephalites, Iniskinites, and Lilloettia.

2. Kepplerites, Pseudocadoceras, and Choffatia?

3. Torricelliceras.

4. Iniskinites.

5. Cobbanites and Grossouvria.

FiguRes 1-4. Index maps showing:

1. General areas in which Bathonian and (or) Callovian ammonites occur in eastern Oregon and westernmost Idaho

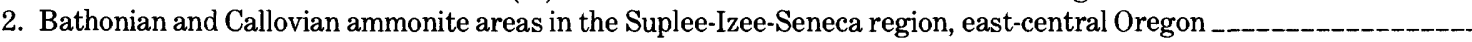

3. Bathonian and Callovian USGS Mesozoic localities from which ammonites were collected in the Izee area, east-central Oregon

4. Bathonian (?) and Callovian ammonite localities near Mineral (abandoned), western Idaho

5. Correlation of some Middle Jurassic (Bathonian and Callovian) formations and faunas in eastern Oregon and southern Alaska

6. Stratigraphic ranges of late Bathonian to middle Callovian ammonites in the Suplee-Izee-Seneca region, east-central Oregon

\section{TABLES}

TABLE 1. Ammonite genera of Bathonian and Callovian Age in eastern Oregon and western Idaho

2. Thicknesses of the Trowbridge Shale in east-central Oregon

3. Stratigraphic positions of Bathonian ammonites in the upper part of the upper member of the Snowshoe Formation, Izee area, Grant County, east-central Oregon

4. Geographic distribution of Bathonian ammonites in the Izee area, Grant County, east-central Oregon

5. Geographic distribution of Callovian or possible Callovian ammonites in eastern Oregon and western Idaho

6. Description of Bathonian and Callovian ammonite localities in east-central Oregon and westernmost Idaho 


\section{CONVERSION FACTORS}

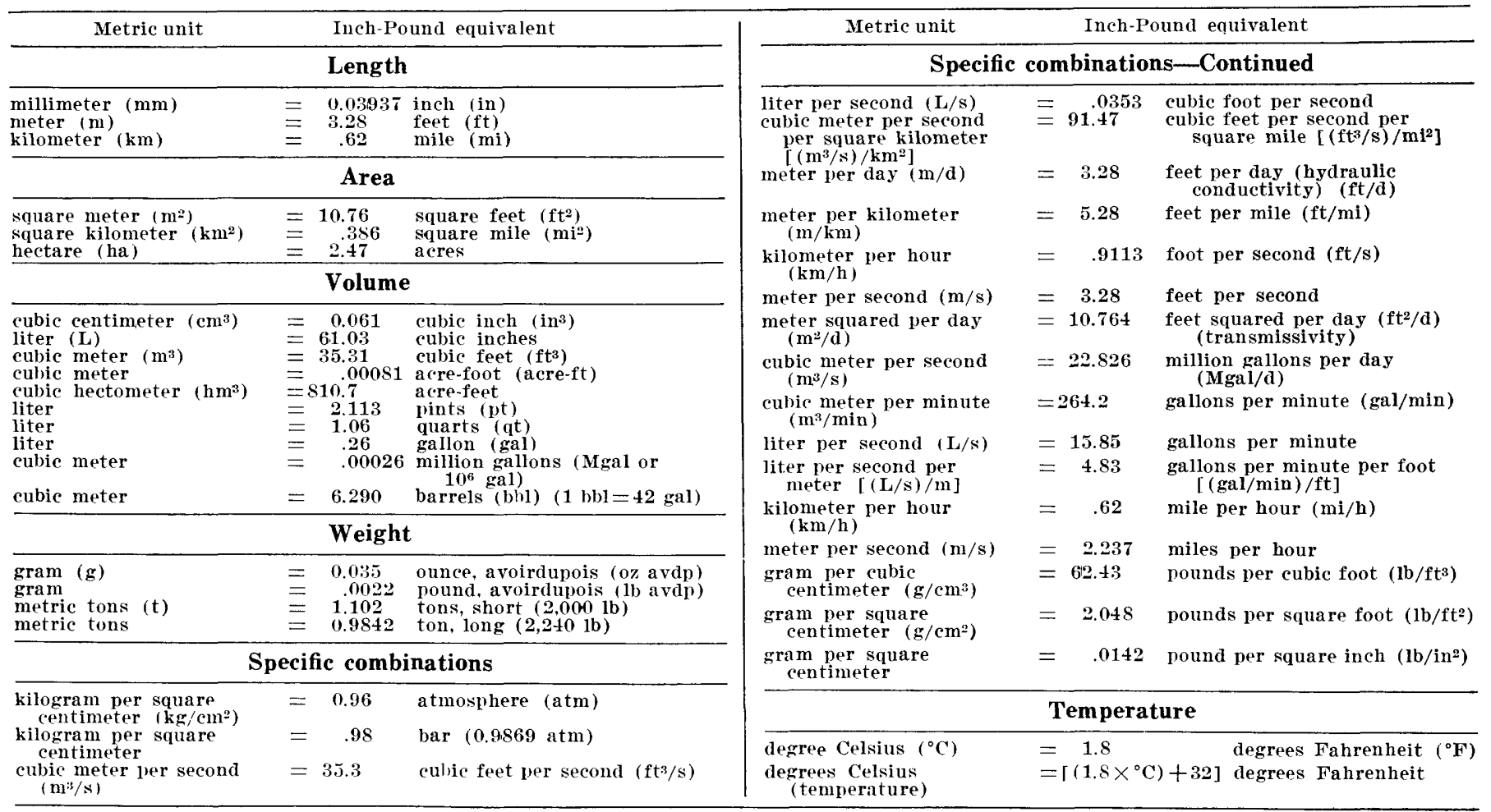




\title{
JURASSIC (BATHONIAN AND CALLOVIAN) AMMONITES IN EASTERN OREGON AND WESTERN IDAHO
}

\author{
By RALPH W. IMLAY
}

\begin{abstract}
Jurassic ammonites of late Bathonian to middle Callovian Age have been found in 12,000-13,000 feet (3,660-3,960 m) of strata exposed in the area near and south of Izee and Seneca in east-central Oregon. Ammonites of early Callovian Age and possibly also late Bathonian Age occur in several hundred feet of black shale exposed along Dennett Creek near Mineral, Idaho. Early Callovian ammonites also occur in similar black shale exposed on the Oregon side of Snake River Canyon about 32 miles $(52 \mathrm{~km})$ south of the northeast corner of Oregon.

The late Bathonian near Izee, Oreg., is represented in the upper 700 feet $(213 \mathrm{~m})$ of the Snowshoe Formation by an association of the ammonites Bullatimorphites, Xenocephalites, Kepplerites, Torricelliceras, Iniskinites, Parareineckeia, Cobbanites, and Choffatia. Such as association also occurs west of Cook Inlet, Alaska, in the upper few hundred feet of the Bowser Formation; this upper part is dated as late Bathonian by one occurrence of the Bathonian genus Cobbanites only 100 feet $(30 \mathrm{~m})$ below an occurrence of Kepplerites, a genus not known below the upper Bathonian. The late Bathonian is also possibly represented near Mineral, Idaho, by an immature ammonite assigned to Cobbanites.
\end{abstract}

The early Callovian near Izee, Oreg., is represented from 1,000 to 1,500 feet ( 305 to $458 \mathrm{~m}$ ) above the base of the Trowbridge Shale by an association of the ammonites Xenocephalites vicarius Imlay, Lilloettia buckmani (Crickmay), L. stantoni Imlay, and Kepplerites. It is represented in the Mineral area of Idaho by the same genera and most of the same species, and it is represented on the Oregon side of Snake River Canyon area near Pittsburg Landing by the same species of Xenocephalites and Lilloettia and by Grossouvria. Such an assemblage occurs west of Cook Inlet, Alaska, in the lower part of the Chinitna Formation, associated with and overlying the highest occurrences of Iniskinites.

No faunal evidence has been found concerning the age of the lower 1,000 feet $(305 \mathrm{~m})$ of the Trowbridge Shale in the Izee area. Nonetheless, the conformable position of this lower part of the Trowbridge below the fossiliferous middle part, its unconformable position above the Snowshoe Formation, and the southwestward overlap of the lower and middle parts of the Trowbridge far beyond the upper member of the Snowshoe Formation are similar to those aspects of the Iniskinites-bearing beds in the basal part of the Chinitna Formation in southern Alaska. The Iniskinites-being beds, formerly considered to be either of latest Bathonian or earliest Callovian Age, are now assigned to the latest Bathonian on the basis of recent discoveries in Canada.

Likewise, no faunal evidence is available concerning the age of the upper part of the Trowbridge Shale in the Izee area, but its stratigraphic position shows that it is of early Callovian age.

The late early to middle Callovian in east-central Oregon is represented in the Lonesome Formation by the presence of (1) Xenocephalites throughout the lower 7,000 feet $(2,134 \mathrm{~m})$ of the forma- tion; (2) Lilloettia at one locality about 1,250 feet (381 m) above the base of the formation; (3) Pseudocadoceras grewingki (Pompeckj) throughout the upper half of the formation; and (4) Pseudocadoceras cf. $P$. grewingki throughout nearly all the formation. In comparison with beds containing the ammonite sequence in southern Alaska, the beds in the Lonesome Formation that contain Xenocephalites and Lilloettia cannot be younger than the middle part of the Paveloff Siltstone Member of the Chinitna Formation, which part is of early middle Callovian Age. The beds containing Pseudocadoceras, however, could represent any part of the Callovian above the basal zone of Macrocephalites macrocephalus. Consideration of both stratigraphic and faunal evidence shows that the Lonesome Formation is approximately equivalent to the Paveloff Siltstone Member and is mostly of middle Callovian Age, but its basal part must be of late early Callovian Age and is probably equivalent to the highest part of the Tonnie Siltstone Member of the Chinitna Formation.

\section{INTRODUCTION}

Some of the ammonites described herein as of late Bathonian to middle Callovian Age were described by the writer in 1964 as entirely of early Callovian Age. After the publication of the 1964 report, many ammonites were collected by H. J. Buddenhagen in 1967; by H. C. Brooks, Gabriel Paris, and T. L. Vallier in 1968; by Tom Hendrickson in 1972; by D. W. Taylor in 1973; by Paul Smith in 1975; and by R. W. Imlay and W. O. Ross in 1965, 1966, 1969, 1973, and 1975. The ammonites collected by H. C. Brooks and T. L. Vallier are from the Oregon side of Snake River Canyon near Pittsburg Landing; those collected by Gabriel Paris and Tom Hendrickson are from the vicinity of Mineral in western Idaho; those collected by H. J. Buddenhagen are mostly from the West Myrtle Butte, Delintment Lake, and Sawtooth Creek Quadrangles, east-central Oregon; those.collected by D. W. Taylor and Paul Smith are from the upper member of the Snowshoe Formation in the Izee Quadrangle, east-central Oregon; and those collected by Imlay and W. O. Ross are from all listed areas in east-central Oregon.

These collections show that certain parts of the formations of Bathonian and Callovian Age are highly fossiliferous, whereas other parts are poorly fossiliferous. Most of the well-preserved ammonites are 
in concretions. Most of the crushed and fragmentary ammonites are on the bedding planes of soft shale and are found mainly in roadcuts. Such occurrences suggest that trenching of shale units whose ages are in doubt should yield identifiable ammonites of age value.

Many thanks are due the geologists listed, particularly H. J. Buddenhagen, for information concerning the stratigraphic occurrences of the fossil collections and the characteristics of the formations of Bathonian and Callovian Age.

\section{BIOLOGIC ANALYSIS}

The Bathonian and Callovian ammonites from Oregon and Idaho that are described or discussed herein number 371 specimens. Their distribution by genus, subfamily, and family is shown on table 1 . Among the nine families represented, the Macrocephalitidae constitute 45 percent, the Cardioceratidae, 42 percent, and the Perisphinctidae, 8 percent of the total specimens.
TABLE 1.-Ammonite genera of Bathonian and Callovian Age in eastern Oregon and western Idaho

\begin{tabular}{|c|c|c|}
\hline Subfamily & Genus & $\begin{array}{c}\text { Number } \\
\text { of } \\
\text { spec- } \\
\text { imens }\end{array}$ \\
\hline Phylloceratidae ___ Phylloceratinae _-_ & Phylloceras. & \\
\hline Do _-_ Calliphylloceratinae & Calliphylloceras_-- & \\
\hline Lytoceratidae & Lytoceras _._._._-_ & \\
\hline Spiroceratidae & Parapatoceras & \\
\hline Tulitidae & Bullatimorphites _. & \\
\hline Macrocephalitidae - & Xenocephalites & 104 \\
\hline Do & Lilloettia & 63 \\
\hline Kosmoceratidae & Kepplerites_. & \\
\hline Do _... & Torricelliceras_._- & \\
\hline Cardioceratidae & Pseudocadoceras & 120 \\
\hline _. do _ _._._. & Pseudocadoceras? _ & \\
\hline Do & Iniskinites & 33 \\
\hline Reineckeidae? _._-_ & Parareineckeia & \\
\hline Perisphinctidae _._ Leptosphinctinae _- & Cobbanites & 19 \\
\hline$=-$ do $_{-}$ & Cobbanites? & \\
\hline Do ___-__-_ Pseudoperisphinc- & Choffatia___._-_-_ & \\
\hline Do _-_ & $C h$ & \\
\hline - do _._- & Grossouvria & 2 \\
\hline
\end{tabular}

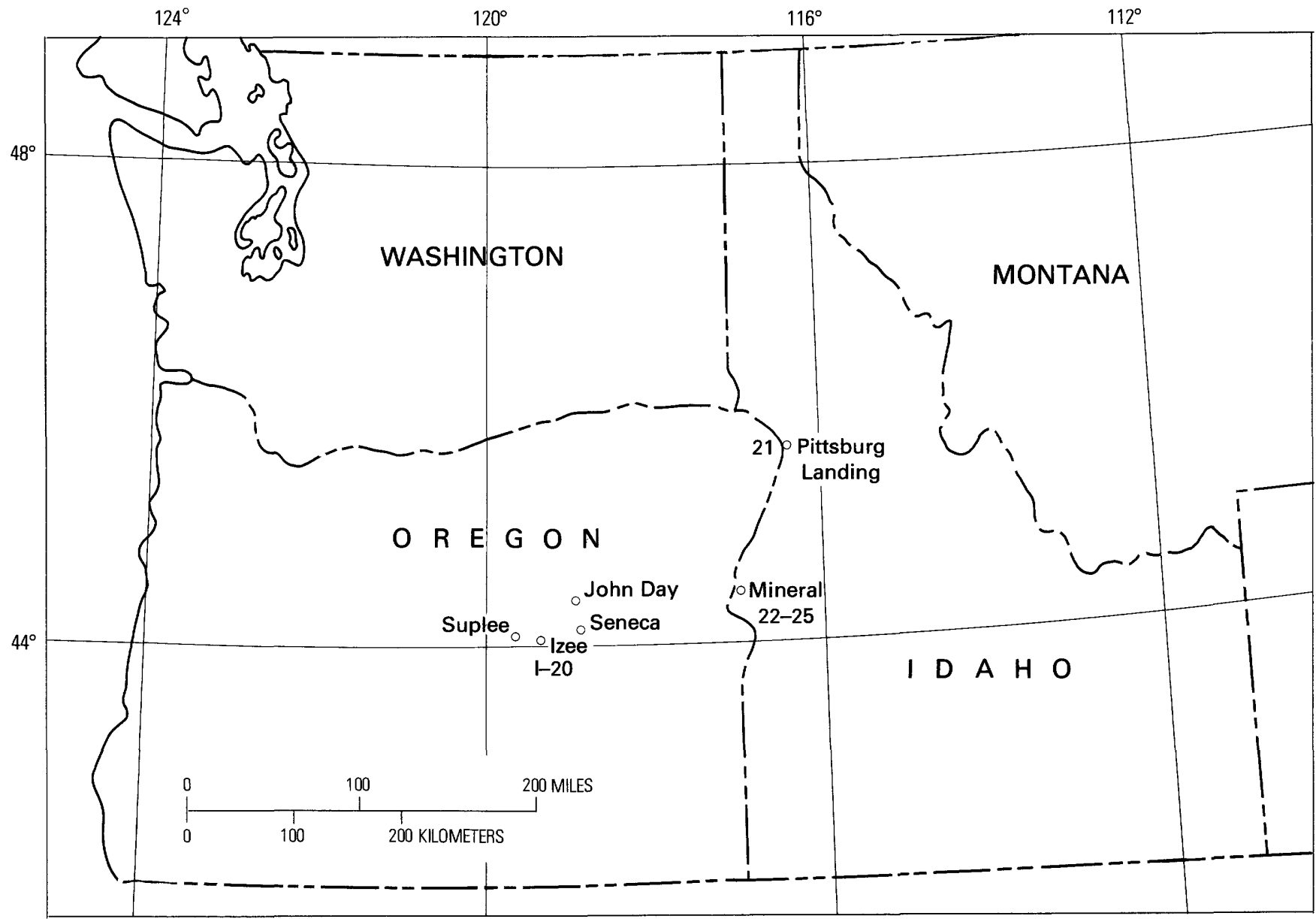

FIGURE 1. - Index map showing general areas in which Bathonian and (or) Callovian ammonites occur in eastern Oregon and westernmost Idaho. Numbered ammonite areas are listed in tables 4 and 5 . 


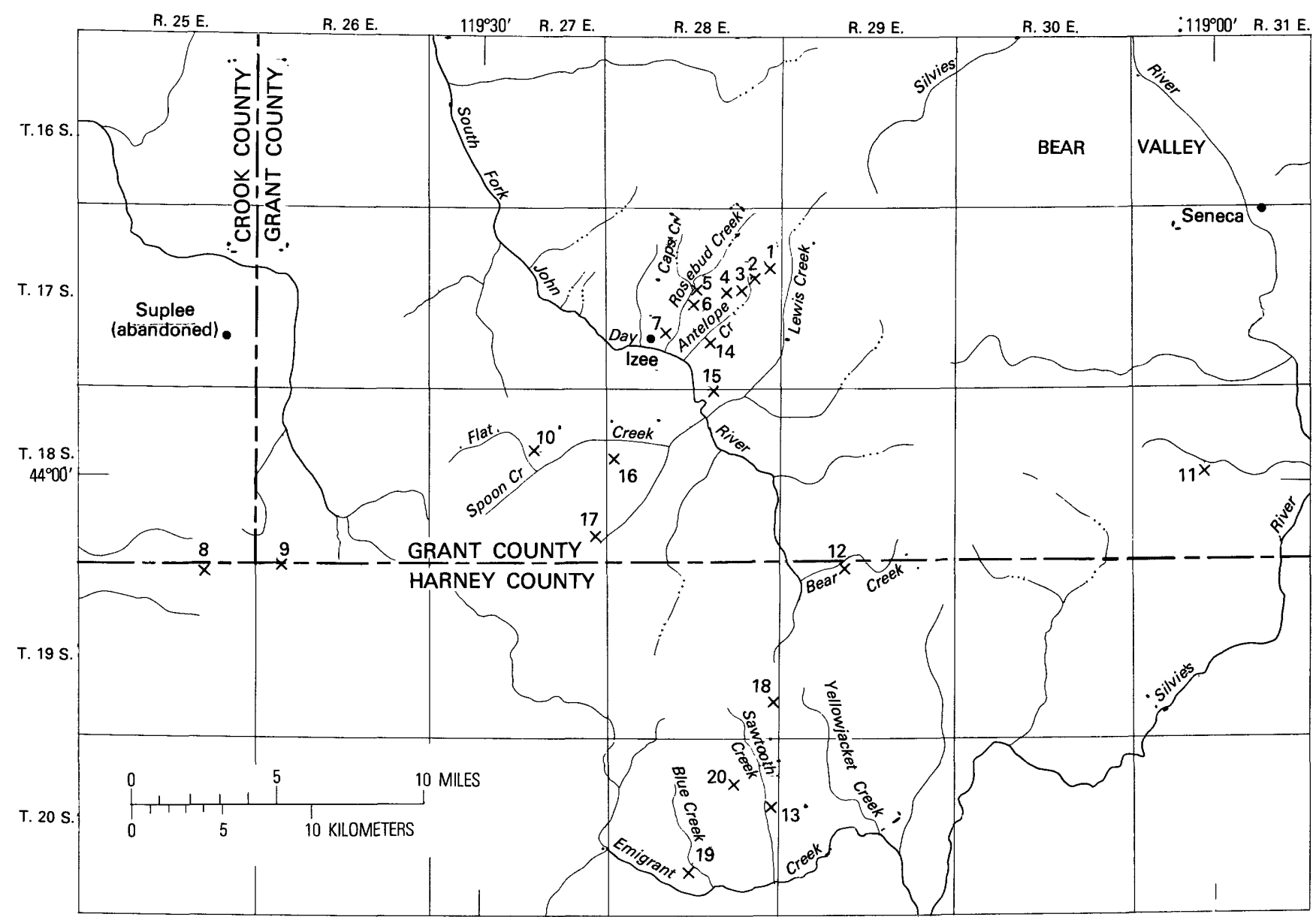

FIGURE 2. - Index map showing Bathonian and Callovian ammonite areas (numbers 1-20) in the Suplee-Izee-Seneca region, east-central Oregon.

\section{STRATIGRAPHIC SUMMARY}

\section{EAST-CENTRAL OREGON}

In the area near and south of Suplee, Izee, and Seneca, in east-central Oregon (figs. 1-4), the Bathonian and Callovian sequence consists from bottom to top of about half the upper member of the Snowshoe Formation and the entire overlying Trowbridge Shale and Lonesome Formation (fig. 5). The upper member of the Snowshoe Formation, as described by Dickinson and Vigrass $(1965$, p. $45-47)$, is about 1,250 feet $(381 \mathrm{~m})$ thick along the South Fork of the John Day River near Izee but thickens northeastward to about 2,000 feet ( 610 $\mathrm{m}$ ) and thins southwestward to a featheredge. It consists of poorly exposed volcanic gray to black laminated mudstone and siltstone that is interbedded with thick beds of gray limy volcanic sandstone. The upper member of the Snowshoe rests conformably on the middle member in most of the Izee area or on the volcaniclastic Silvies Member near the head of Lewis Creek. Its contact with the overlying Trowbridge Shale is sharp, is marked by a change from laminated mudstone and sandstone to massive black or green mudstone, and is an unconformity, as is shown by gradual but complete southwestward overlap of the Trowbridge Shale onto the middle member of the Snowshoe Formation (Dickinson, 1962a, p. 252; 1962b, p. 483). No faunal evidence for the existence of the upper member of the Snowshoe Formation has been found in the Sawtooth Creek, West Myrtle Butte, and Delintment Lake Quadrangles. 


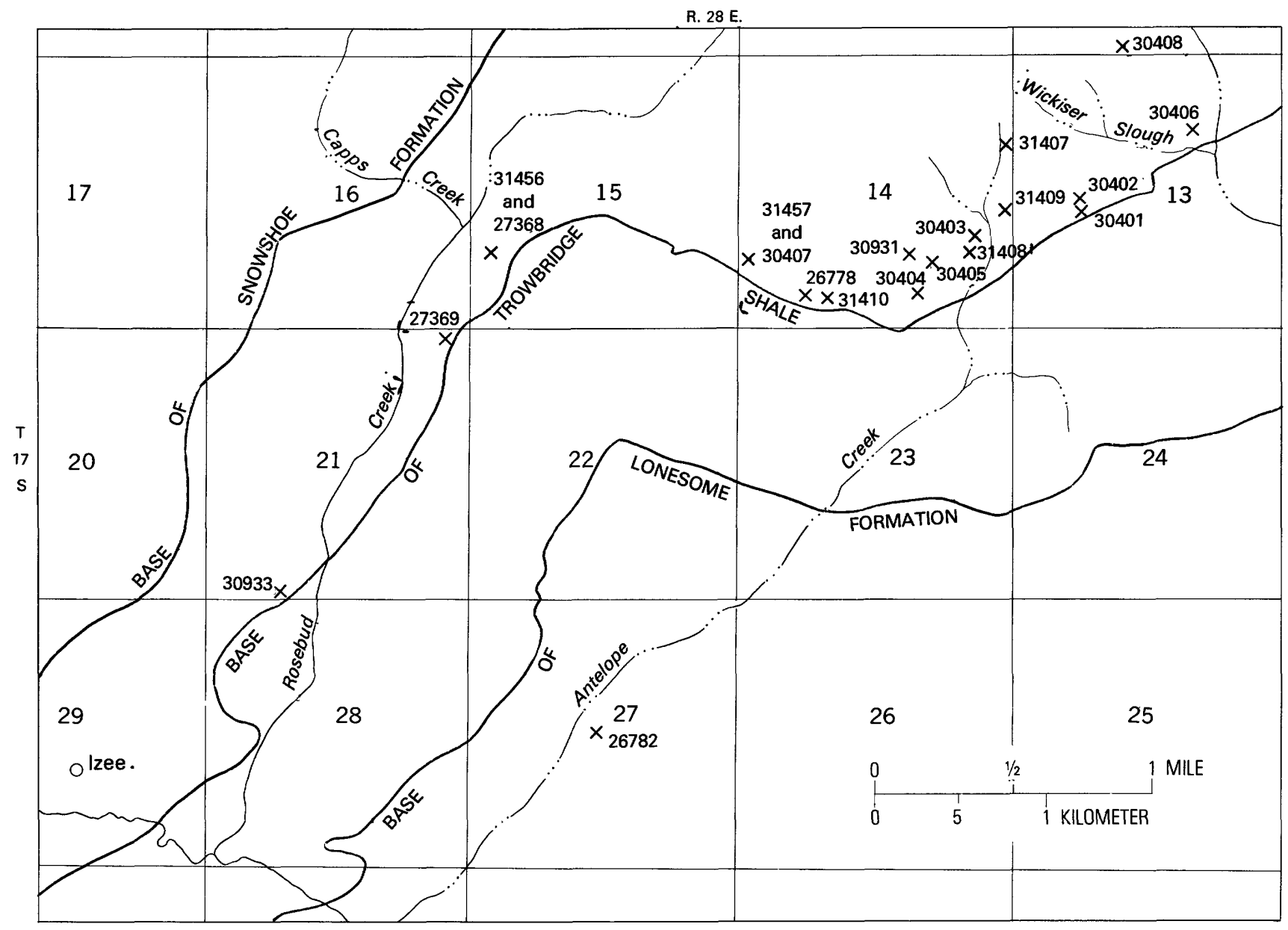

FIGURE 3.-Index map showing Bathonian and Callovian USGS Mesozoic localities from which ammonites were collected in the Izee area, east-central Oregon.

The Trowbridge Shale exposed in the Izee Quadrangle thickens northeastward from 2,250 feet $(686 \mathrm{~m})$ on Flat Creek to 3,250 feet (991 m) on Lewis Creek (table 2) and consists mostly of black to green mudstone and shale characterized by marble-sized black concretions. It is divisible into three members on the basis of the presence of some interbedded volcaniclastic beds (middle member) that thicken northeastward from 100 feet (30.5 m) on Flat Creek to 500 feet $(152 \mathrm{~m})$ on Lewis Creek (Dickinson and Vigrass, 1965, p. 60-64, 96; Dickinson, 1962a, p. 252) and that overlie 400-500 feet (122-152 m) of black to green mudstone (lower member) in the type area near Izee.

Southward from the Izee Quadrangle, similar changes in the Trowbridge Shale take place from east to west, according to studies made by H. J. Buddenhagen (written communs., 1967, 1969,1977, 1978). Thus, in the northwestern part of the Delintment Lake Quadrangle, the formation is about 1,000 feet $(305 \mathrm{~m})$ or less in thickness and consists mostly of black mudstone and shale. About 10 miles $(16 \mathrm{~km})$ to the east near Alder Creek, the Trowbridge Shale is at least 1,600 feet ( 488 m) thick. Another 10 miles $(16 \mathrm{~km})$ farther east near Bear Creek, the Trowbridge contains some thin units of fine-grained sandstone and tuff in its upper part and is at least 2,000 feet $(610 \mathrm{~m})$ thick. Another 13 miles (21 $\mathrm{km}$ ) east-northeast of the Bear Creek area, near Jack Andy Creek, the Trowbridge is at least 3,800 feet $(1,159$ $m$ ) thick and consists partly of interbedded shale and tuffaceous siltstone and partly of black laminated shale; it also contains many thin to thick beds of sandstone, of which some are tuffaceous. These data show that the Trowbridge Shale becomes much thicker and sandier eastward over a distance of about 33 miles $(53 \mathrm{~km})$.

The Trowbridge Shale near Izee rests unconformably on beds of different ages (Dickinson and Vigrass, 1965, p. 84). Near Izee, its lower member rests on the upper member of the Snowshoe Formation, which is herein dated as of latest Bathonian Age. Six miles to the southwest, at Big Flat, the middle member of the 


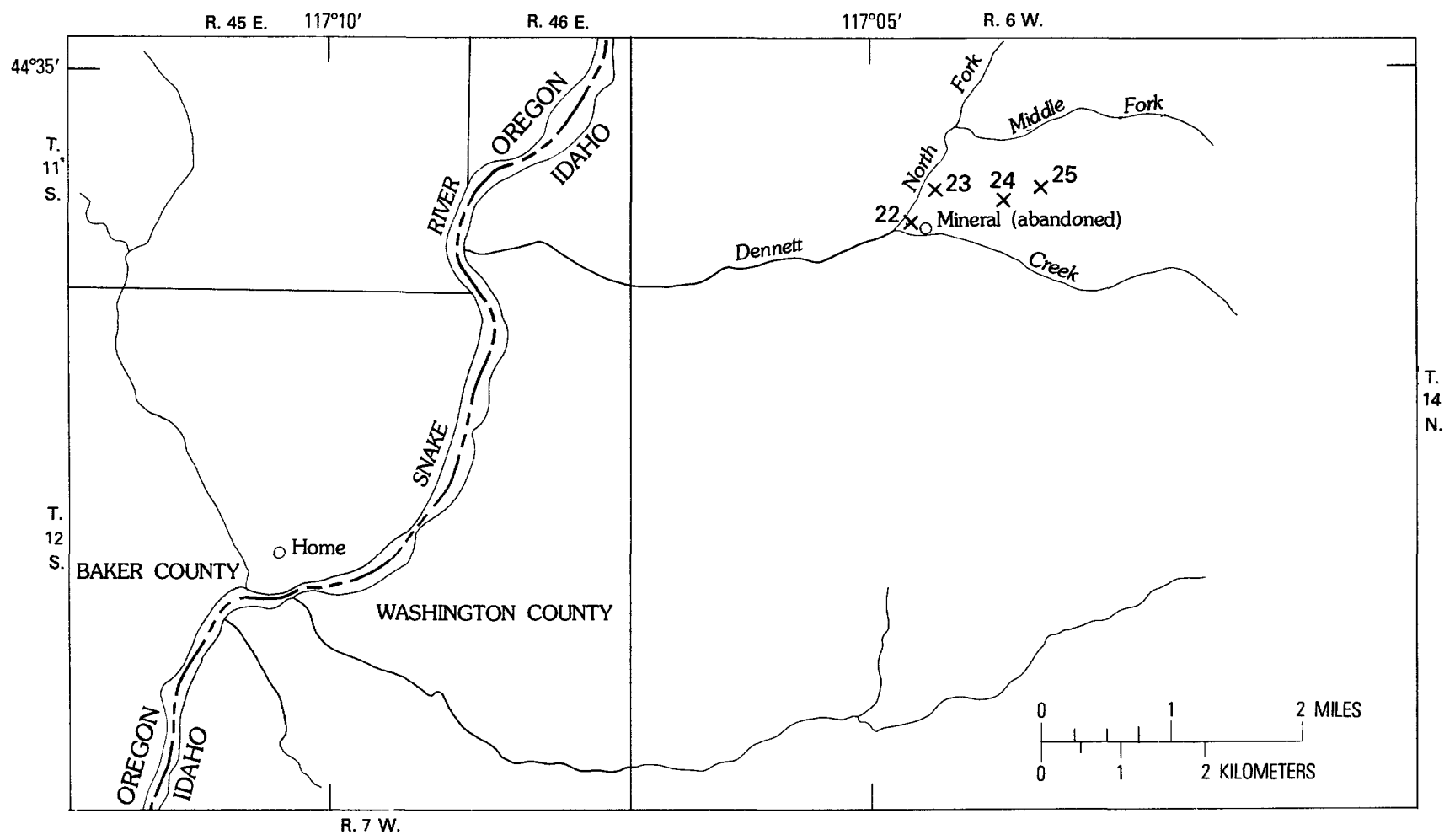

FigURE 4. - Index map showing Bathonian (?) and Callovian ammonite areas (numbers 22-25) near Mineral (abandoned), western Idaho.

TABLE 2. - Thicknesses of the Trowbridge Shale in east-central Oregon

\begin{tabular}{llll}
\hline \multicolumn{1}{c}{ Area } & \multicolumn{1}{c}{ Approximate thickness } & \multicolumn{1}{c}{ Section, township, and range } & Quadrangle \\
County
\end{tabular}

Trowbridge Shale rests on the middle member of the Snowshoe Formation of late middle Bajocian Age (Imlay, 1973, p. 10). About 20 miles southwest of Izee, in the northwestern part of the Delintment Creek Quadrangle, the Trowbridge Shale, probably represented only by its upper member as exposed near Izee, rests unconformably on the Basey Member of the Snowshoe Formation of late middle Bajocian Age (H. J. Buddenhagen, written commun., 1969). East of the Delintment Lake Quadrangle, the upper part of the Snowshoe Formation directly underlying the Trowbridge Shale contains ammonites of late middle Bajocian Age at Emigrant Creek (Imlay, 1973, p. 30) in the south-central part of the Sawtooth Quadrangle and at Bear Creek in the north- eastern part of the same quadrangle. Evidently the Trowbridge Shale transgressed both westward and southward from the Izee area.

The unconformity at the base of the Trowbridge Shale apparently formed at the same time as that at the base of the Chinitna and Shelikof Formations in southern Alaska. Thus, the Chinitna Formation in the Talkeetna Mountains rests on beds ranging in age from late Bathonian to Early Jurassic (Imlay and Detterman, 1973, p. 14,15 ; Imlay, 1975 , p. 8, 9, 14). West of Cook Inlet, between Tuxedni Bay and Iniskin Bay, the Chinitna Formation rests unconformably on the Bowser Formation (Bathonian), whose upper part is truncated northward (Detterman and Hartsock, 1966, p. 42; Imlay and Det- 


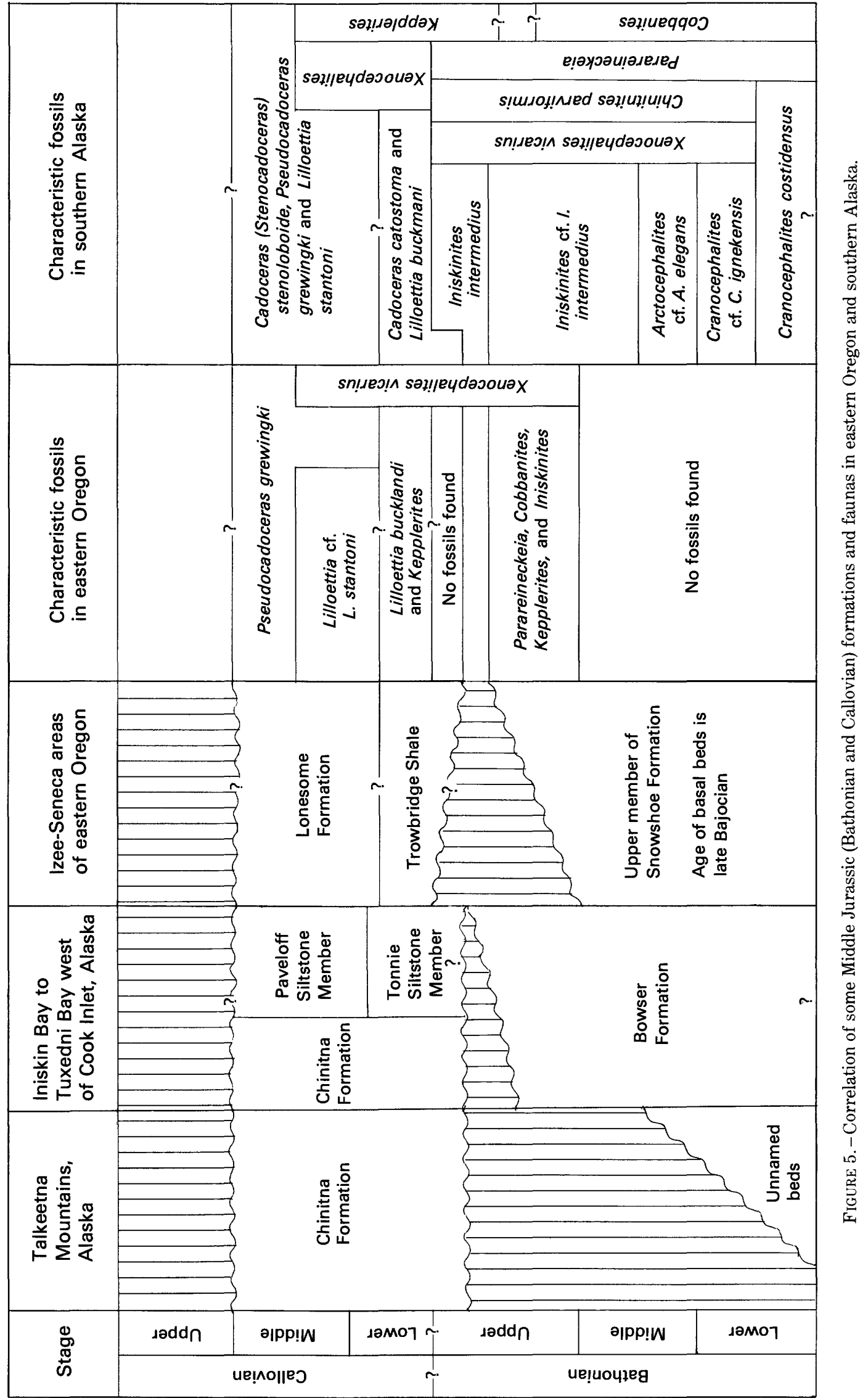


terman, 1973 , p. 14, 15; Imlay, 1975 , p. 14). On the Alaska Peninsula, the Shelikof Formation rests unconformably on beds of early middle Bajocian Age (Imlay and Detterman, 1973, p. 15; 1977, p. 610). These remarkable similarities in areas now far apart (fig. 5) could be explained if the areas were once much closer together or if the sea level over great distances in the Pacific Coast region became somewhat lower during formation of the unconformity and then appreciably higher during deposition of the Chinitna and Shelikof Formations and Trowbridge Shale. The fact that Cadoceras is absent in the Callovian beds of eastern Oregon but is abundant in those beds in Alaska suggests that the two areas were fairly far apart during Callovian time.

The Lonesome Formation crops out in the southeastern part of the Izee Quadrangle in Grant County, in the northern and eastern parts of the Sawtooth Creek Quadrangle in Grant and Harney Counties, and in the northern part of the West Myrtle Butte Quadrangle in the same two counties. Its type section along the South Fork of the John Day River in the Izee quadrangle is well exposed, is at least 10,000 feet $(3,150 \mathrm{~m})$ thick, rests conformably on the Trowbridge Shale, and consists of thin to thick units of hard, massive volcanic gray to green graywacke that are characterized by graded bedding and sole markings and that alternate with thin to thick units of massive dark-gray to black siltstone, claystone, and mudstone (Dickinson and Vigrass, 1965, p. 64-67; Dickinson, 1962b, p. 483). The Lonesome Formation exposed in the Sawtooth Creek and West Myrtle Butte Quadrangles is similar lithologically and in thickness to the type section but differs by being less well exposed and more folded. Megafossils are rather sparse throughout all sections. The Lonesome Formation is overlain by Tertiary volcanic rocks.

\section{SNAKE RIVER CANYON AREA IN IDAHO AND OREGON}

Unnamed Jurassic beds exposed near Mineral (abandoned), Idaho (fig. 4), consist, from the base upward, of (1) about 300 feet $(91 \mathrm{~m})$ of a coarse conglomerate; (2) about 100 feet $(30 \mathrm{~m})$ of dark-gray thin-to thick-bedded sandy tuff; and (3) several hundred feet of dark-gray calcareous concretionary shale. The upper part of the tuff contains Gryphaea culebra Imlay, which has been found in eastern Oregon northwest of Brogan in association with such early Bajocian ammonites as Eudmetoceras, Erycitoides, and Tmetoceras (USGS Mesozoic loc. 30142). Concretions in the upper unit of dark shale contain ammonites that are identical with those of Callovian Age in the Trowbridge Shale in the Izee area of east-central Oregon.

Unnamed Jurassic rocks occur on the Oregon side of Snake River Canyon about 32 miles $(52 \mathrm{~km})$ south of the northeast corner of Oregon near Pittsburg Landing (fig.
1). These rocks consist of black shale and brown graywacke, are tightly folded, are at least several hundred feet thick, and rest unconformably on Upper Triassic rocks (Vallier, 1968, p. 247). The fossils present consist mostly of ammonites identical with those in similar shaly beds near Mineral, Idaho, and in the Trowbridge Shale of east-central Oregon. Other fossils include a fish scale, a large tooth, and belemnite fragments.

\section{AGES AND CORRELATIONS}

\section{SNOWSHOE FORMATION IN EAST-CENTRAL OREGON}

The lower and middle members of the Snowshoe Formation in the Izee area are dated by ammonites as late Toarcian to late middle Bajocian, as discussed elsewhere (Imlay, 1968, p. C14, C16, C44-C46; 1973, p. 25-30). The basal part of the upper member is dated as early late Bajocian by the presence of Leptosphinctes (Imlay, 1973, p. $15,25,91$, pl. 47 , fig. 24). Above is $800-900$ feet (244-274 m) of beds that have not furnished any ammonites but that, on the basis of stratigraphic position, should represent the latest Bajocian and most of the Bathonian. In contrast, the upper 700 feet $(213 \mathrm{~m})$ of the upper member has provided many ammonites that were once considered to be of late Bathonian or early Callovian Age, or both (Imlay, 1964, p. D8, D9). The ammonites are now definitely assigned to the late Bathonian (figs. 5 and 6) on the basis of a comparison with recently studied Callovian and Bathonian ammonites from southern Alaska (Imlay, 1975; 1979).

The ammonite genera of age significance in the upper part of the upper member of the Snowshoe Formation include Bullatimorphites, Xenocephalites, Kepplerites, Torricelliceres, Iniskinites, Parareineckeia, Cobbanites, and Choffatia (tables 3 and 4). They do not include Lilloettia, whose former identification (Imlay, 1964, p. D7) was based on immature specimens of Iniskinites. Most genera of age significance are all associated at one locality (USGS Mesozoic loc. 26778) about 150 feet (46 $\mathrm{m}$ ) below the top of the member; some are associated at two or three localities (table 4) that are lower stratigraphically. In addition, the lowest occurrences of Xenocephalites, Kepplerites, Torricelliceras, Iniskinites, and Cobbanites are 550-700 feet (168-214m) stratigraphically below the top of the upper member (table 3). These data compared with those for the ranges of the same ammonite genera in southern Alaska, as discussed herein, make possible a definite late Bathonian Age assignment for the uppermost part of the Snowshoe Formation. 


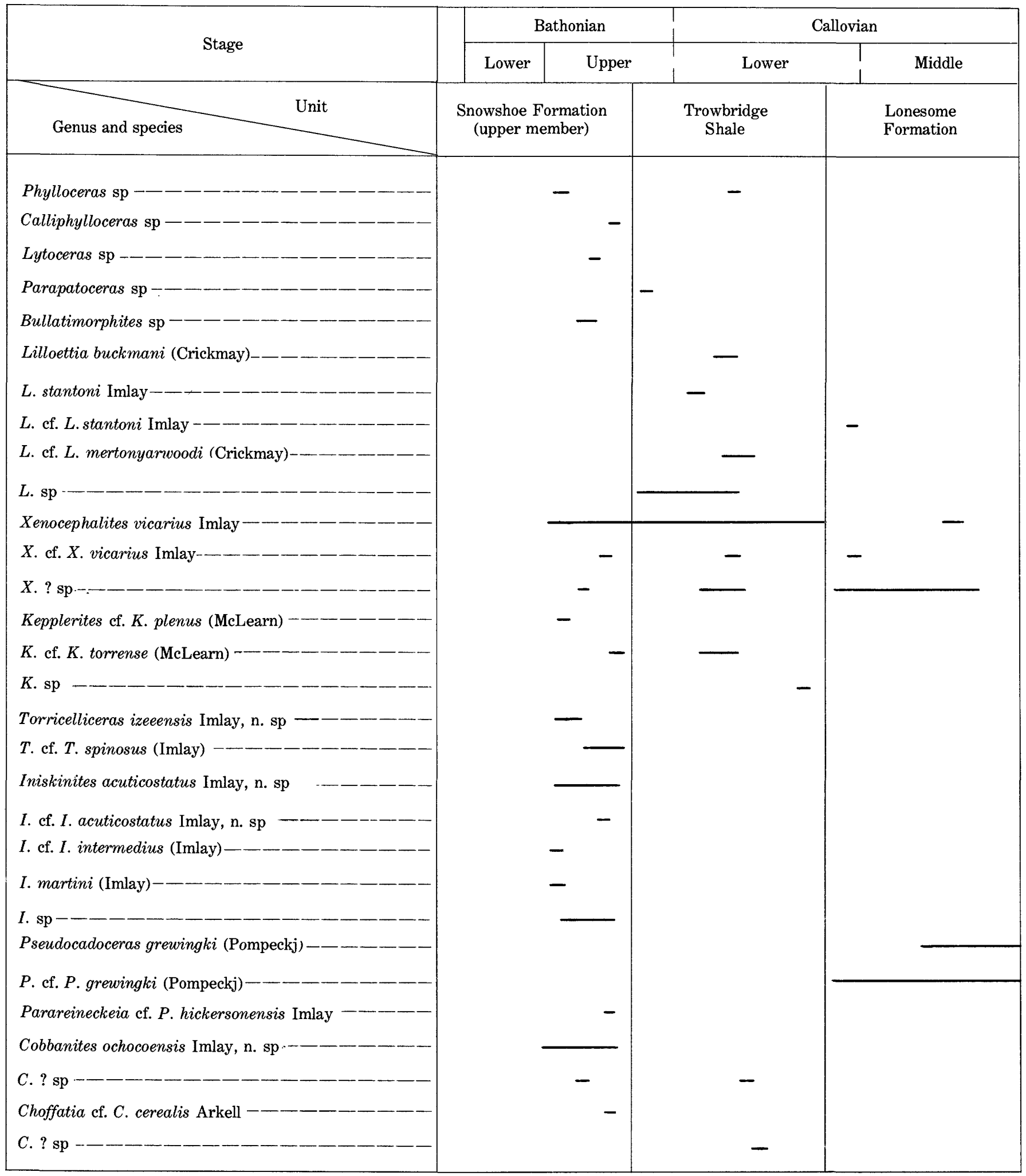

FIGURE 6. - Stratigraphic ranges of late Bathonian to middle Callovian ammonites in the Suplee-Izee-Seneca region, east-central Oregon. (Most fossils were collected where the upper member of the Snowshoe Formation is about 1,500 $\mathrm{ft}(457 \mathrm{~m})$ thick, the Trowbridge Shale about 2,250 ft (686 m) thick, and the Lonesome Formation about 10,000 ft (3,050 m) thick.) 
TABLE 3-Stratigraphic positions of Bathonian ammonites in the upper part of the upper member of the Snowshoe Formation, Izee area, Grant County, east-central Oregon

\begin{tabular}{|c|c|}
\hline Genera and species & $\begin{array}{l}\text { Positions in feet (meters) } \\
\text { below top of formations }\end{array}$ \\
\hline 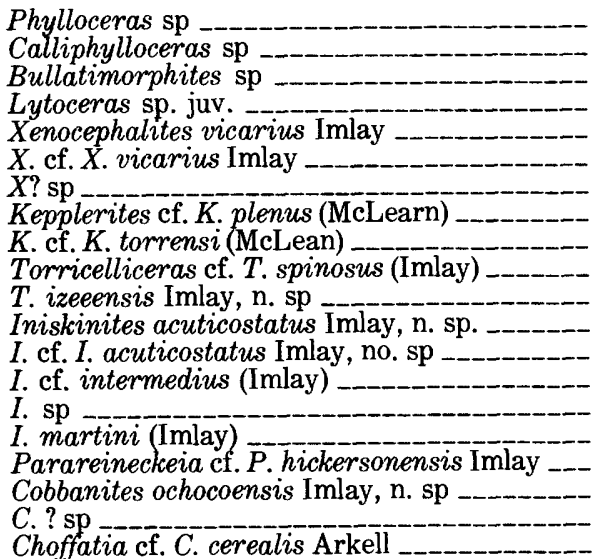 & $\begin{array}{l}580(177) \\
150(46) \\
450(137) \\
310(95) \\
150-620(46-189) \\
220(67) \\
380(116) \\
550(168) \\
85-150(26-46) \\
150(46) \\
450-580(137-177) \\
110-600(34-183) \\
220(67) \\
600(183) \\
165-620(50-189) \\
640(195) \\
150(46) \\
85-700(26-213) \\
380(116) \\
150(46)\end{array}$ \\
\hline
\end{tabular}

Of the genera listed (table 3), Bullatimorphites in Eurasia ranges through the Bathonian and most of the Callovian (Hahn, 1971, p. 96). The subgenus Bomburites ranges through the upper Bathonian into the middle Callovian but is most common in the basal Callovian (Hahn, 1971, p. 59, 106). The compressed species that Enay $(1959$, p. 253) assigned to Treptoceras are reported by him $(1959$, p. 255-258) to range through the upper Bathonian into the lowermost Callovian (Macrocephalites macrocephalus zone). Kepplerites ranges from upper Bathonian to upper lower or lower middle Callovian.
Xenocephalites in southern Alaska is fairly common throughout the Bowser Formation above the basal beds characterized by Cranocephalites costidensus Imlay (Imlay, 1979), is common in the lower part of the Tonnie Siltstone Member of the Chinitna Formation (Imlay, 1975 , p. 3, 6, 7), and is represented by a single specimen from near the middle of the Paveloff Siltstone Member of the Chinitna Formation (Imlay, 1953, p. 69, 78, pl. 29, figs. 6,$7 ; 1975$, p. 7 ). Its occurrences in the Bowser Formation represent most of the Bathonian, and occurrences in the lower part of the Chinitna Formation represent both uppermost Bathonian and lowermost Callovian; its single occurrence in the Paveloff Siltstone Member represents lower middle Callovian. The species $X$. vicarius Imlay in Alaska has been found only in the lower part of the Chinitna Formation and in the uppermost part of the Bowser Formation.

Kepplerites in the Cook Inlet region of southern Alaska is rare in the upper few hundred feet of the Bowser Formation and is fairly common throughout the lower three-fourths of the Chinitna Formation. Its age range in Alaska is late Bathonian to early or early middle Callovian. In the Bowser Formation, it is stratigraphically near Iniskinites and Cobbanites. In the basal part of the Chinitna Formation, it is associated with Lilloettia, Iniskinites, Xenocephalites, and Cadoceras. In the uppermost part of its range, it is commonly associated with Cadoceras and Pseudocadoceras (Imlay, 1975), p. 6). Whether any occurrence is younger than early middle Callovian is doubtful.

Torricelliceras west of Cook Inlet is represented by $T$. spinosus (Imlay), which is found a little below the middle

TABLE 4. -Geographic distribution of Bathonian ammonites in the Izee area, Grant County, east-central Oregon [Numbered areas 1-7 are shown in figs. 1 and 2]

\begin{tabular}{|c|c|c|c|c|c|c|c|c|c|c|c|c|c|c|c|c|c|c|c|}
\hline \multirow{3}{*}{ Genus and species } & \multicolumn{19}{|c|}{ Upper member of Snowshoe Formation } \\
\hline & \multicolumn{2}{|c|}{1} & \multicolumn{4}{|c|}{2} & \multicolumn{5}{|c|}{3} & \multicolumn{4}{|c|}{4} & \multicolumn{2}{|c|}{5} & 6 & \multirow[b]{2}{*}{ 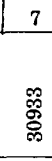 } \\
\hline & 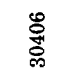 & 号 & 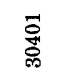 & 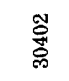 & $\stackrel{\widetilde{W}}{\tilde{W}}$ & 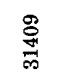 & $\begin{array}{l}\text { ờ } \\
\text { 商 }\end{array}$ & 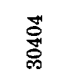 & 总 & 芯 & $\underset{\text { 蒠 }}{\infty}$ & 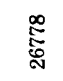 & 害 & $\frac{\sqrt{0}}{\operatorname{d}}$ & $\frac{0}{\vec{j}}$ & 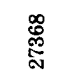 & 蚛 & 总 & \\
\hline 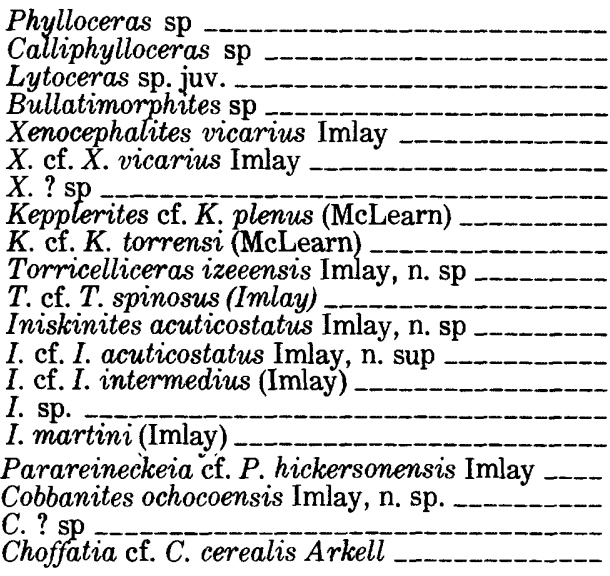 & $\overline{\mathrm{X}}$ & 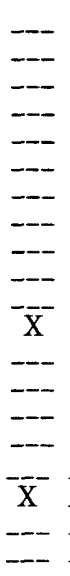 & 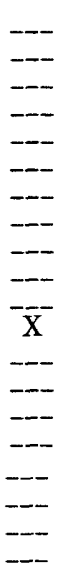 & 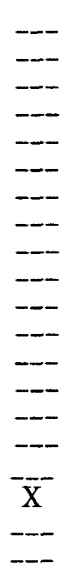 & 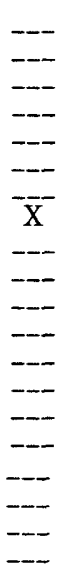 & \begin{tabular}{c}
- \\
- \\
- \\
\hdashline- \\
\hdashline- \\
- \\
\hdashline- \\
- \\
- \\
-
\end{tabular} & 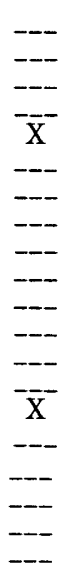 & 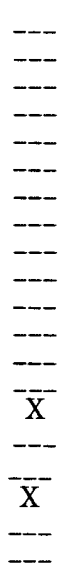 & 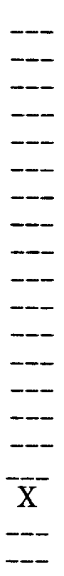 & $\begin{array}{l}--- \\
-- \\
-- \\
-- \\
-- \\
-- \\
-- \\
-- \\
--- \\
-\bar{X} \\
-\end{array}$ & 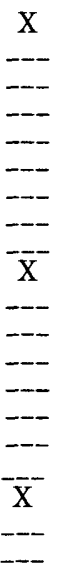 & 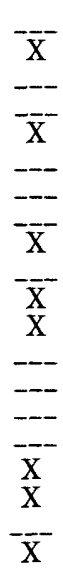 & 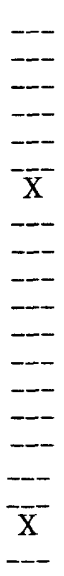 & 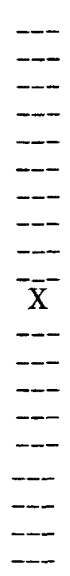 & 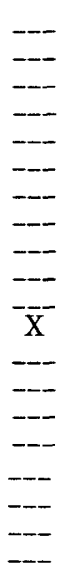 & $\begin{array}{c}\overline{-} \overline{\mathrm{X}} \\
\overline{-} \\
--- \\
-- \\
-- \\
-- \\
-- \\
-- \\
--- \\
--\end{array}$ & $\begin{array}{c}\bar{X} \\
\bar{X} \\
- \\
\\
\\
- \\
\bar{X}\end{array}$ & $\begin{array}{c}\bar{X} \\
-\bar{X} \\
- \\
- \\
-\end{array}$ & $\begin{array}{l}- \\
- \\
- \\
- \\
- \\
- \\
- \\
-- \\
-- \\
- \\
\mathrm{X}\end{array}$ \\
\hline
\end{tabular}


of the Tonnie Siltstone Member of the Chinitna Formation and just above the range of Iniskinites (Imlay, 1975, p. 6). It should be of early Callovian Age and a little younger than a specimen from eastern Oregon that has similar ornamentation.

Iniskinites west of Cook Inlet, in southern Alaska, occurs in the upper part of the Bowser Formation as well as in the basal part of the Chinitna Formation. It is associated in the lowest part of its range with the highest occurrences of Cranocephalites and the lowest occurrence of Xenocephalites. Higher in the Bowser Formation it is associated with Kepplerites, Cobbanites, and Chinitnites. Those three genera and Iniskinites also are found in the lower two-fifths of the Tonnie Siltstone Member of the Chinitna Formation associated with Lilloettia, Xenocephalites, and Cadoceras. These associations indicated that Iniskinites in southern Alaska ranges in age from late middle Bathonian to at least late Bathonian. Furthermore, the highest occurrences in the basal part of the Chinitna Formation are herein dated as latest Bathonian Age. The fact that Iniskinites acuticostatus Imlay, n. sp., in the upper member of the Snowshoe Formation is not associated with Lilloettia or Cadoceras indicates that the member is not as young as the basal part of the Chinitna Formation, which contains those genera in association with $I$. intermedius (Imlay).

As both species of Iniskinites are useful in making fairly close age determinations, the Iniskinites intermedius subzone of Imlay $(1975$, p. 7$)$ is herein raised to the rank of a zone, and the overlying Cadoceras catostoma zone in southern Alaska is restricted to occurrences of that species above the range of Iniskinites. The new zone of Iniskinites intermedius also includes occurrences of that species below the range of Lilloettia and Cadoceras, as in the uppermost part of the Bowser Formation in southern Alaska. Similarly, a new zone of Iniskinites acuticostatus is herein established for the faunal sequence in the upper part of the Snowshoe Formation of eastern Oregon, as described herein.

Parareineckeia west of Cook Inlet is represented in the basal part of the Bowser Formation by $P$. hickersonensis Imlay in association with Cranocephalites costidensus Imlay. At Wide Bay on the Alaska Peninsula, it is represented in the lower part of the lower member of the Shelikof Formation by $P$. shelikofana (Imlay), which is at about the same stratigraphic position as the lowest occurrence of Lilloettia buckmani (Crickmay) but below all local occurrences of Iniskinites and Cadoceras (Imlay, 1975, p. 12). These occurrences show that Parareineckeia ranges throughout the entire Bathonian and that, because of its presence in the Shelikof Formation, it could also be of earliest Callovian Age. The close resemblance of the Oregon specimen described as Parareineckeia cf. P. hickersonensis Imlay to the inner whorls of $P$. hickersonensis Imlay from southern Alaska definitely suggests a Bathonian Age for the upper part of the upper member of the Snowshoe Formation.

Cobbanites in southern Alaska occurs with Cranocephalites costidensus Imlay in the Wrangell and Talkeetna Mountains. West of Cook Inlet at Tuxedni Bay, Cobbanites was collected about 150 feet $(46 \mathrm{~m})$ below the top of the Bowser Formation within a sequence containing Iniskinites and Kepplerites and about 140 feet $(43 \mathrm{~m})$ above Cranocephalites. These occurrences represent most of the Bathonian. Such an age for the upper part of the upper member of the Snowshoe Formation is favored, therefore, by the presence of $\mathrm{Cob}$ banites at stratigraphic positions ranging from 85 to 700 $\mathrm{ft}$ ( 26 to $213 \mathrm{~m}$ ) below the top of that formation.

Choffatia is represented west of Cook Inlet by one large specimen (Imlay, 1953, p. 102, pl. 54, figs. 1, 2; Arkell, 1956, p. 536) that is associated with Iniskinites intermedius (Imlay, 1953, p. 81; 1975, p. 4, 6) in the basal beds of the Chinitna Formation. This occurrence is herein dated as latest Bathonian in age. As Choffatia in Eurasia ranges in age from middle Bathonian to middle Callovian (Arkell and others, 1957, p. L317; Arkell, 1958, p. 211), it is not useful in determining the exact age of the uppermost part of the Snowshoe Formation of eastern Oregon.

In summation, the upper part of the upper member of the Snowshoe Formation in east-central Oregon is dated as late Bathonian by a comparison of its ammonite assemblage with assemblages in the Bathonian and Callovian sequences of southern Alaska (fig. 5). Such a date is proved by the association of Kepplerites, Iniskinites, Parareineckeia, and Cobbanites throughout most of the upper $600-700$ feet $(183-213 \mathrm{~m})$ of the Snowshoe Formation (see table 3 and fig. 6); by the fact that Kepplerites in southern Alaska and East Greenland has not been found below beds of late Bathonian Age; by the presence of Cobbanites in southern Alaska only in beds of Bathonian Age; by the absence in the Snowshoe Formation of Lilloettia and Cadoceras, which in southern Alaska do not occur below the Chinitna Formation; and by the close resemblance of an immature specimen of Parareineckeia in the Snowshoe Formation to $P$. hickersonensis Imlay from the Bathonian of Alaska. This evidence does not prove that the uppermost part of the Snowshoe Formation represents the very uppermost Bathonian. Evidently that age is represented in Alaska by the lowest part of the Chinitna Formation that is characterized by the highest oecurrences of Iniskinites, Chinitnites, and Xenocephalites vicarius Imlay in association with the lowest occurrences of Cadoceras and Lilloettia. That age could be 
represented in eastern Oregon by the lowest part of the Trowbridge Shale.

\section{TROWBRIDGE SHALE IN EAST-CENTRAL OREGON}

Ammonites have been found in dark shale in the Trowbridge Shale in at least four small areas (table 5; fig. 6). Most of them were found in the southwestern corner of the Izee Quadrangle on the north side of Flat Creek in the central and east-central parts of sec. 15, $\mathrm{T}$. 18 S., R. 27 E., Grant County, at stratigraphic positions ranging from about 1,000 to 1,500 feet (305 to $457 \mathrm{~m}$ ) above the base of the formation, which is about 2,250 feet $(686 \mathrm{~m}$ ) thick. (See localities listed under column 10, table 5.)

In the Izee area, the lower part of the Trowbridge Shale could be, on the basis of stratigraphic position, of latest Bathonian to early Callovian Age or entirely early Callovian. Its middle part is dated as early Callovian by an association of the ammonites Lilloettia buckmani (Crickmay), L. stantoni Imlay, Xenocephalites vicarius Imlay, and Kepplerites cf. T. torrensi (McLearn) (table 5) and by the absence of Iniskinites. Thus, Lilloettia in southern Alaska is not known below the Chinitna Formation, Xenocephalites is rare above the lower two-fifths of the Chinitna Formation, and Kepplerites ranges from the uppermost part of the Bowser Formation throughout about three-fourths of the Chinitna Formation (Imlay, 1975, p. 6, 7, 13). The unfossiliferous but conformable upper part of the Trowbridge Shale in the Izee area is likewise dated as early Callovian on the basis of its conformable stratigraphic position below the Lonesome Formation, which contains ammonites of late early to middle Callovian Age. The unfossiliferous lower part of the Trowbridge Shale in the Izee area occupies the same stratigraphic position as the basal beds of the Shelikof and Chinitna Formations of southern Alaska that likewise rest disconformably on beds of late Bathonian to middle Bajocian Age and likewise are conformable upward with beds of early Callovian Age.

It follows that at least part of the unfossiliferous lower part of the Trowbridge Shale should be of the same age as the basal beds of the Chinitna and Sheilikof Formations that contain as association of Iniskinites and Cadoceras. Such an association, according to Hans Frebold (written commun., 1978), is definitely late Bathonian on the basis of comparison with an ammonite assemblage from the northern Yukon that contains species in common with the highest Bathonian of East Greenland.

In the northwestern corner of the Delintment Lake Quadrangle, ammonites from the basal beds of the Trowbridge Shale include Parapatoceras and Xenocephalites vicarius Imlay (USGS Mesozoic locs. 29799 and 29800); from 600 to 700 feet (183 to $213 \mathrm{~m}$ ) above the base, they include Lilloettia stantoni Imlay and $X$. vicarius Imlay. In the southeastern part of the Sawtooth Creek quadrangle, $X$. cf. $X$. vicarius Imlay was collected (USGS Mesozoic loc. 28666) about 1,200 feet $(366 \mathrm{~m})$ above the base of the Trowbridge Shale, which is at least 2,000 feet $(610 \mathrm{~m})$ thick and may be faulted at its top. In the northeastern part of the West Myrtle Butte Quadrangle near Jack Andy Creek, Kepplerites sp.(USGS Mesozoic loc. 31454) was collected in the upper part of the Trowbridge Shale about 3,100 feet $(945 \mathrm{~m})$ above its base. Nearby, in the southeastern corner of the Logdell Quadrange, $X$. cf. $X$. vicarius Imlay (USGS Mesozoic loc. 29419 and 29420) was probably collected near the top of the Trowbridge Shale, which is estimated as at least 3,800 feet $(1,159 \mathrm{~m})$ thick.

In the Delintment Lake area, the association of Parapatoceras and Xenocephalites in the basal beds of the Trowbridge Shale shows that those beds are either of late Bathonian or early Callovian Age. The presence of Lilloettia stantoni Imlay considerably above the basal beds shows that the upper part of the formation in that area is of early or early middle Callovian Age on the basis of a comparison with the ammonite succession in southern Alaska (Imlay, 1975), p. 6, 14). Correlation of the entire Trowbridge Shale in the Delintment Lake area with only the upper member of the Trowbridge Shale in the type area near Izee is favored by the fact that the lower member disappears southwestward from Izee within a few miles and that the middle member thins markedly southwestward to only 100 feet $(30 \mathrm{~m})$ on Flat Creek (Dickinson and Vigrass, 1965, p. 60, 61, 84).

The presence of Kepplerites near the top of the Trowbridge shale in the Logdell Quadrangle indicates that the formation is not younger than the earliest middle Callovian of Europe or the middle part of the Paveloff Siltstone Member of the Chinitna Formation in southern Alaska (Imlay, 1975, p. 6, 14).

\section{LONESOME FORMATION IN EAST-CENTRAL OREGON}

The Lonesome Formation in east-central Oregon is characterized by Xenocephalites vicarius Imlay or by $X$. cf. $X$. vicarius Imlay throughout its lower 7,000 feet $(2,134 \mathrm{~m})$, by Lilloettia cf. $L$. stantoni Imlay at one place about 1,250 feet $(381 \mathrm{~m})$ above its base, by Pseudocadoceras grewingki (Pompeckj) near its middle and top, and by $P$. cf. C. grewingki throughout its upper 9,500 feet $(2,896 \mathrm{~m})$ (see fig. 6 and table 5). When comparisons are made with the Callovian ammonite sequence in southern Alaska, the occurrences of these three genera are good evidence that the Lonesome Formation correlates with much of the Alaskan Chinitna and Shelikof Formations above the beds characterized by Iniskinites and that its age must be late early to middle Callovian. 
TABLE 5.-Geographic distribution of Callovian or possible

[Numbered areas 8-25 are shown

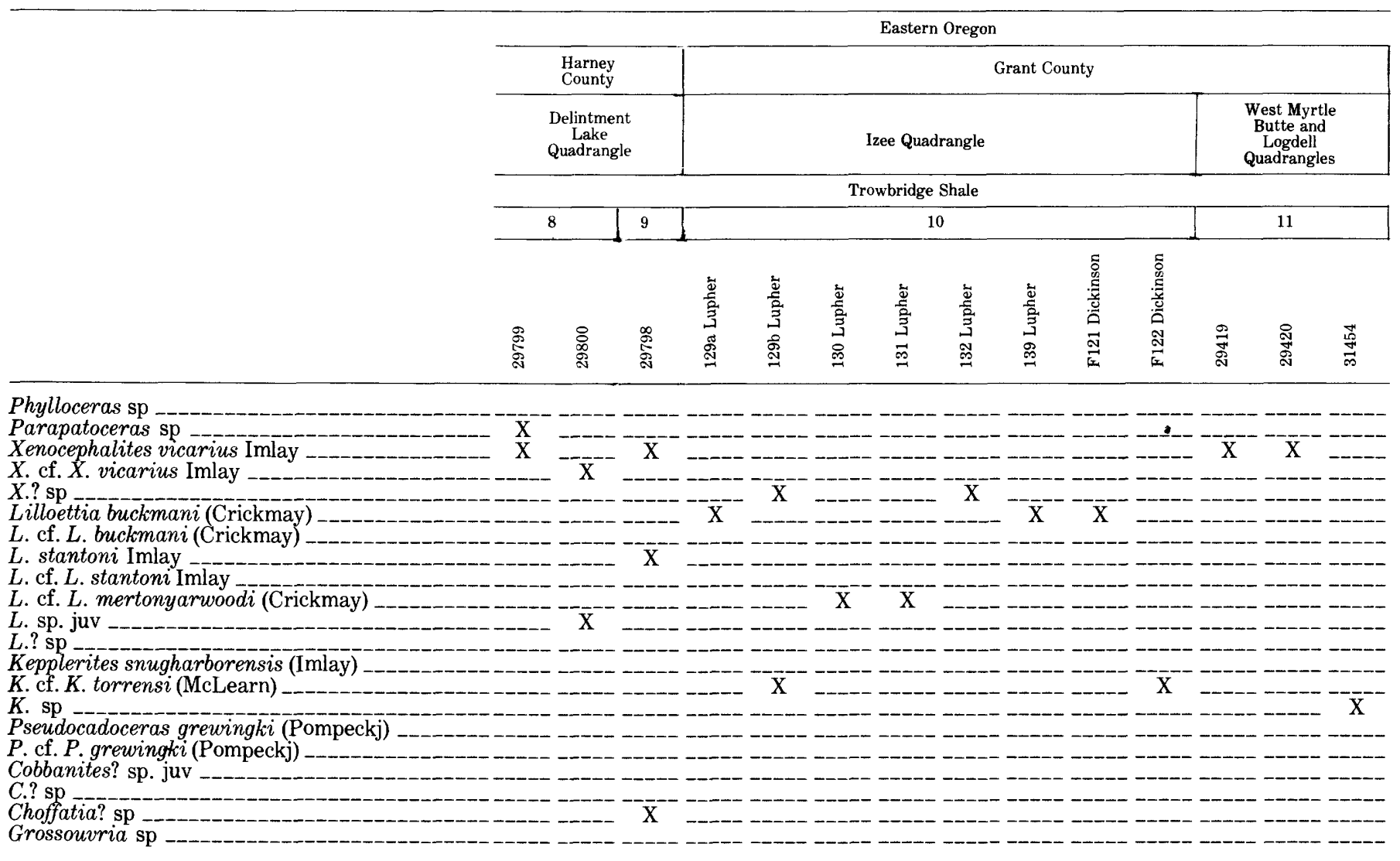

JURASSIC BEDS NEAR MINERAL, WESTERN IDAHO

Ammonites from Livingston's locality 88 (Livingston, 1932 , p. 33, 34) near the abandoned mining town of Mineral, Idaho, include an association of Lilloettia buckmani (Crickmay) and Xenocephalites vicarius Imlay (Imlay, 1964, p. D6, D7), which in eastern Oregon occur together in the middle part of the Trowbridge Shale and in southern Alaska occur together in the lower part of the Tonnie Siltstone Member of the Chinitna Formation. At another place in the Mineral area (USGS Mesozoic loc. 30082), Lilloetia cf. L. buckmani Crickmay is associated with Kepplerites snugharborensis (Imlay), which in the Tuxedni Bay area, of southern Alaska, occurs in the basal beds of the Chinitna Formation (Imlay, 1975 , p. 4, 6). In addition, near Mineral, the ammonite Xenocephalites was found (USGS Mesozoic loc. 28651) in association with a small immature ammonite that resembles the inner whorls of Cobbanites talkeetnanus Imlay $(1962$, pl. 7, figs. 10,11) from southern Alaska and from the highest part of the Snowshoe Formation near Izee, in eastern Oregon, as figured herein (pl. 5, figs. 1, 4-8). If the specimen from the Mineral area actually is
Cobbanites, then beds of Bathonian Age are definitely present near Mineral. On the basis of comparison with the faunal sequence in southern Alaska, the beds near Mineral that contain these ammonites are of latest Bathonian to early Callovian Age.

\section{JURASSIC BEDS NEAR PITTSBURG LANDING IN NORTHEAST OREGON}

Some black shale exposed on the Oregon side of the Snake River near Pittsburg Landing likewise may be correlated with the Trowbridge Shale of eastern Oregon and with the lower part of the Chinitna Formation in southern Alaska; the correlation is shown by the association of Lilloettia stantoni Imlay, Xenocephalites vicarius Imlay, and Grossouvria. The presence of Grossouvria shows that the beds are of early Callovian rather than of latest Bathonian Age.

\section{AMMONITE FAUNAL SETTING}

The late Bathonian ammonite genera of east-central Oregon are of diverse origin. Those characteristic of the Pacific realm include Xenocephalites, Iniskinites, 
Callovian ammonites in eastern Oregon and western Idaho

in fig. 1]

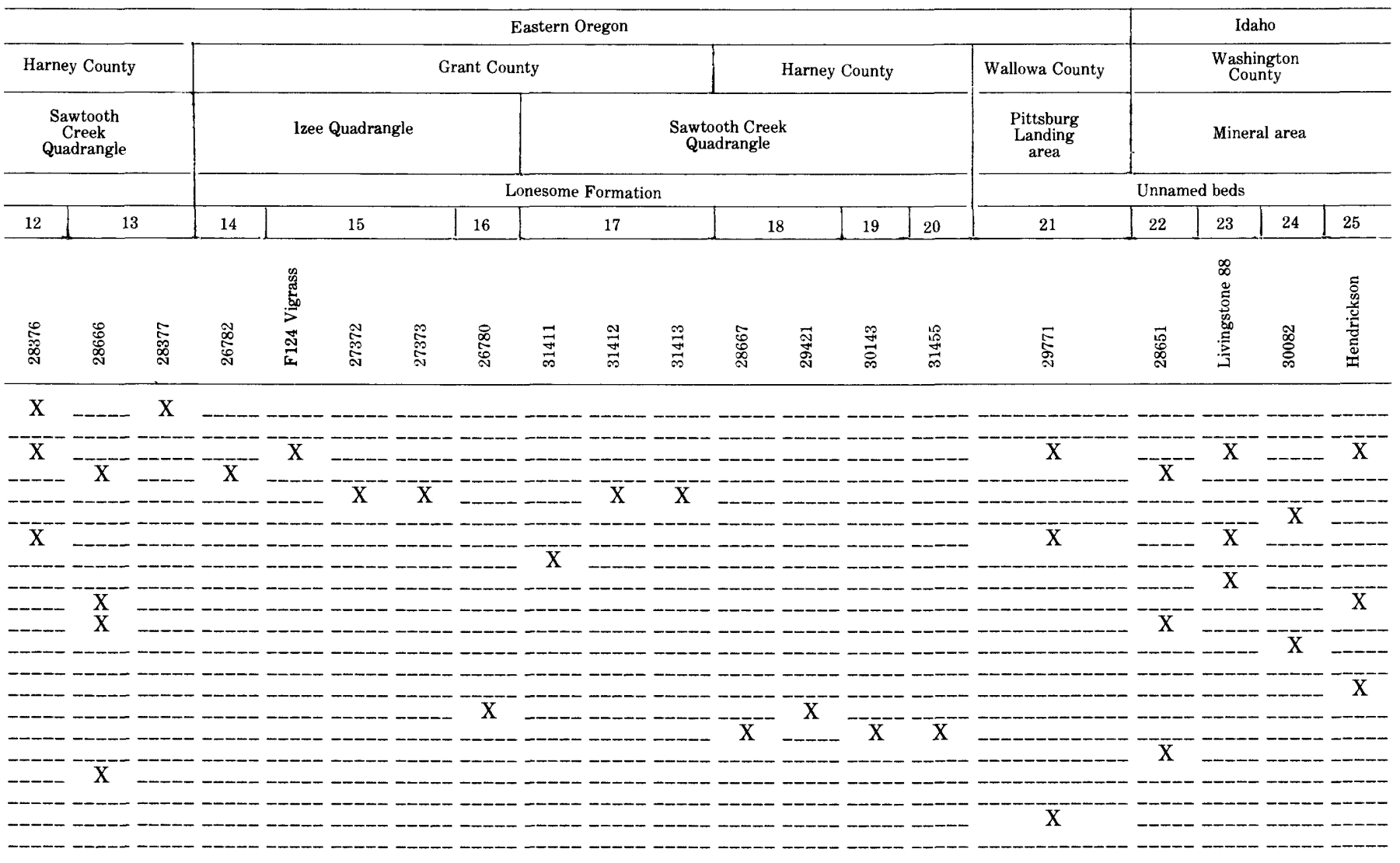

Parareineckeia, and Cobbanites. Those found most commonly in the Boreal realm include Kepplerites and Torricelliceras. Those that occur nearly worldwide but are rarely Boreal include Phylloceras, Calliphylloceras, Lytoceras, and Choffatia. Ammonites representing the Pacific and Boreal realms have much in common specifically with ammonites in British Columbia and southern Alaska.

The early to middle Callovian ammonites of eastern Oregon and western Idaho are likewise of diverse origin. Xenocephalites and Lilloettia are characteristic of the Pacific Realm. Kepplerites and Pseudocadoceras are characteristic of the Boreal realm. Parapatoceras and Grossouvria are nearly worldwide outside the Boreal realm, and Phylloceras occurs mainly outside the Boreal realm. These ammonites occur as two assemblages, of which the lower of early Callovian Age includes all the genera listed and the upper includes Pseudocadoceras and Xenocephalites. Neither assemblage contains Cadoceras or its subgenera Paracadoceras and Stenocadoceras that are common in Alaska in beds of Callovian Age.

\section{GEOGRAPHIC DISTRIBUTION}

The geographic occurrences of the Bathonian and Callovian ammonites from eastern Oregon and westernmost Idaho described herein are shown in tables 4 and 5 and figures 1-4. Detailed descriptions of the occurrences are given in table 6 .

TABLE 6.-Description of Bathonian and Callovian ammonite localities in east-central Oregon and westernmost Idaho

\begin{tabular}{cccc}
\hline Area & USGS & Collector's & Collector, year of collection, \\
No. & Mesozoic & field & stratigraphic assignment, \\
(figs. & locality & No. & description of locality \\
$1-3)$ & No. & &
\end{tabular}

1 _-_- $30406 \quad$ I73-6-27A __-_-_- R. W. Imlay and W. O. Ross, 1973. Snowshoe Formation, upper member, about $220 \mathrm{ft}$ $(67 \mathrm{~m})$, below top. North side of Wickiser Slough in $\mathrm{NE}^{1 / 4} \mathrm{SW}^{1 / 4} \mathrm{NE}^{1 / 4}$ sec. 13 , T. 17 S., R. 28 E., Izee Quad., Grant County, Oreg. 
TABLE 6.-Description of Bathonian and Callovian ammonite localities in east-central Oregon and westernmost Idaho-Continued

\begin{tabular}{|c|c|c|c|}
\hline $\begin{array}{c}\text { Area } \\
\text { No. } \\
\text { (figs. } \\
1-3 \text { ) }\end{array}$ & $\begin{array}{c}\text { USGS } \\
\text { Mesozoic } \\
\text { locality } \\
\text { No. }\end{array}$ & $\begin{array}{l}\text { Collector's } \\
\text { field } \\
\text { No. }\end{array}$ & $\begin{array}{l}\text { Collector, year of collection, } \\
\text { stratigraphic assignment, } \\
\text { description of locality }\end{array}$ \\
\hline
\end{tabular}

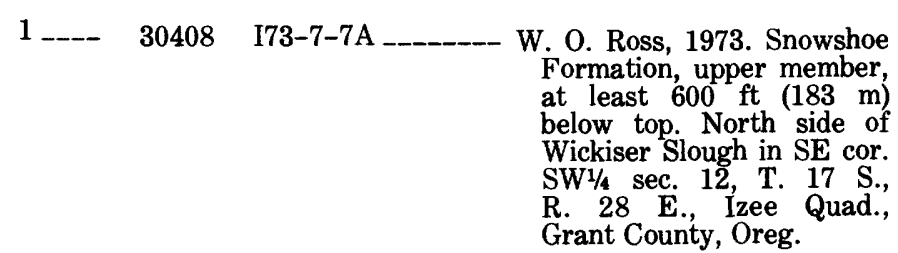

2 -_- $30401 \quad$ 173-6-25A _-_-_ R. W. Imlay and W. O. Ross, 1973. Snowshoe Formation, upper member, $110 \mathrm{ft}(34 \mathrm{~m})$ below top on divide between Little Antelope Creek and Wickiser Slough in $\mathrm{NE}^{1 / 4}$ $\mathrm{NW}^{1 / 4} \mathrm{SW}^{1 / 4}$ sec. 13, T. 17 S., R. 28 E., Izee Quad., Grant County, Oreg.

2 _-_- $30402 \quad$ I73-6-25C _-___- R. W. Imlay and W. O. Ross, 1973. Snowshoe Formation, upper member $210 \mathrm{ft}(64 \mathrm{~m})$ below top. About $200 \mathrm{ft}$. $(61 \mathrm{~m})$ northwest of USGS Mesozoic loc. 30401.

2 ___- 31407 PSU-A-0744 _-_ D. W. Taylor, 1973. Snowshoe Formation, upper member, about $550 \mathrm{ft}$. $(168 \mathrm{~m})$ below top. On steep west-facing hillside about $600 \mathrm{ft}(183 \mathrm{~m})$ south of north end of field in $\mathrm{NE}$ cor. $\mathrm{SE}^{1 / 4} \mathrm{NE}^{1 / 4}$ sec. 14, T. 17 S., R. 28 E., Izee Quad., Grant County, Oreg.

2 ____ 31409 PSU-A-0753 _-_- D. W. Taylor, 1973. Snowshoe Formation, upper member, about $600 \mathrm{ft}(183 \mathrm{~m})$ below top. On steep south-facing hillside in east-central part of $\mathrm{NE}^{1 / 4 \mathrm{NE}^{1 / 4}} \mathrm{SE}^{1 / 4}$ sec. 14 , T. 17 S., R. 28 E., Izee Quad., Grant County, Oreg.

3 -_- $\quad 30403 \quad$ I73-6-25C _ ___- R. W. Imlay and W. O. Ross, 1973. Snowshoe Formation, upper member, at least 620 ft $(189 \mathrm{~m})$ below top. $\mathrm{SW}^{1 / 4} \mathrm{NE}^{1 / 4} \mathrm{SE}^{1 / 4}$ sec. $14, \uparrow$. 17 S., R. 28 E., Izee Quad., Grant County, Oreg.

3 _-_ $30404 \quad$ I73-6-26A _._._- W. O. Ross and R. W. Imlay, 1973. Snowshoe Formation, upper member $300-400 \mathrm{ft}$ (91-122 m) below top. On third low southeast. trending ridge west of head of Antelope Creek, slightly east of center of SW1/4 SE1/4 sec. 14, T. 17 S., R. 28 E., Izee Quad., Grant County, Oreg.

3 ___- $\quad 30405 \quad$ I73-6-26B ___-_ W. O. Ross and R. W. Imlay, 1973. Snowshoe Formation upper member, about $700 \mathrm{ft}$ $(215 \mathrm{~m})$ below top. On second low southeasttrending ridge west of head of Antelope Creek, $\mathrm{NE}^{1 / 4} \mathrm{SW}^{1 / 4} \mathrm{SE}^{1 / 4}$ sec. 14, T. 17 S., R. 28 E., Izee Quad., Grant County, Oreg.
TABLE 6.-Description of Bathonian and Callovian ammonite localities in east-central Oregon and westernmost Idaho-Continued

\begin{tabular}{|c|c|c|c|}
\hline $\begin{array}{c}\text { Area } \\
\text { No. } \\
\text { (figs. } \\
1-3 \text { ) }\end{array}$ & $\begin{array}{c}\text { USGS } \\
\text { Mesozoic } \\
\text { locality } \\
\text { No. }\end{array}$ & $\begin{array}{l}\text { Collector's } \\
\text { field } \\
\text { No. }\end{array}$ & $\begin{array}{l}\text { Collector, year of collection, } \\
\text { stratigraphic assignment, } \\
\text { description of locality }\end{array}$ \\
\hline $3 \ldots$ & 30931 & I75-8-15B & $\begin{array}{l}\text { R. W. Imlay, } 1975 \text {. Snowshoe } \\
\text { Formation, upper member, } \\
\text { about } 640 \text { ft }(195 \mathrm{~m}) \text { below } \\
\text { top. Near base of north side } \\
\text { of first gulch south of main } \\
\text { hayfield in Antelope Creek, } \\
\text { south-central part of } \\
\text { NE } 1 / 4 \mathrm{SE}^{1 / 4} \text { sec. } 14 \text {, T. } 17 \mathrm{~S} ., \\
\text { R. } 28 \mathrm{E} \text {., Izee Quad., Grant, } \\
\text { County, Oreg. }\end{array}$ \\
\hline
\end{tabular}

3 _-_ 31408 PSU-A-0745 _-_- D. W. Taylor, 1973. Snowshoe Formation, upper member, about $580 \mathrm{ft}(177 \mathrm{~m})$ below top. At east end of small east-trending ridge about $600 \mathrm{ft}(183 \mathrm{~m})$ west of valley floor, $\mathrm{SE}$ cor. $\mathrm{SW}^{1 / 4} \mathrm{NE}^{1 / 4} \mathrm{SE}$ $1 / 4$ sec. 14, T. 17 S., R. 28 E., Izee Quad., Grant County, Oreg.

4 -__- 26778 F115(3-48-1) -_- W. R. Dickinson and R.W. Imlay, 1957, Snowshoe Formation, upper member, $150 \mathrm{ft}(46 \mathrm{~m})$ below top. From 50-75 ft (15-23 m) northeast of road in eastcentral part of SW1/4 SW $1 / 4$ sec. 14, T. 17 S., R. 28 E., Izee Quad., Grant County, Oreg.

4 -_-_ 31457 Loc. E _-_ Paul Smith, 1975, Snowshoe Formation, upper member. Float collected about $450 \mathrm{ft}$ $(137 \mathrm{~m})$ below top. Near USGS Mesozoic loc. 30407, about $500 \mathrm{ft}(152 \mathrm{~m})$ northwest of USGS Mesozoic loc. 26778 , on south bank of short gully on east side of road to old Parish Ranch in $\mathrm{SW}^{1 / 4} \mathrm{SW}^{1 / 4}$ sec. 14, T. $17 \mathrm{~S}$., R. 28 E., Izee Quad., Grant County, Oreg.

4 _-__ $30407 \quad$ I73-6-29A _____- R. W. Imlay and W. O. Ross, 1973. Snowshoe Formation, upper member, about $380 \mathrm{ft}$ $(116 \mathrm{~m})$ below top. Just northwest of road in $\mathrm{SW}^{1 / 4}$ $\mathrm{SW}^{1 / 4}$ sec. 14 , T. 17 S., R. 28 E., Izee Quad., Grant County, Oreg.

4 -_ 31410 PSU-A-0811 _ D. W. Taylor, 1973. Snowshoe Formation, upper member, about $150 \mathrm{ft}(46 \mathrm{~m})$ below top. On hillside east of road and $260 \mathrm{ft}(79 \mathrm{~m}) \mathrm{N} .18^{\circ} \mathrm{W}$. of point where fence line along ridge crosses road, in $\mathrm{SE}^{1 / 4} \mathrm{SW}^{1 / 4}$ sec. 14 , T. $17 \mathrm{~S}$., R. 28 E., Izee Quad., Grant County, Oreg

5 ___- $27368 \quad$ I58-8-28A _____- R. W. Imlay, 1958. Snowshoe Formation, upper member, about $310 \mathrm{ft}(94 \mathrm{~m})$ below top. East side of Rosebud Creek southeast of mouth of Capps Creek in $\mathrm{SW}^{1 / 4} \mathrm{NW}^{1 / 4}$ SW $1 / 4$ sec. 15 , T. 17 S., R. 28 E., Izee Quad., Grant County Oreg. 
TABLE 6.-Description of Bathonian and Callovian ammonite localities in east-central Oregon and westernmost Idaho-Continued

\begin{tabular}{cccc}
\hline $\begin{array}{c}\text { Area } \\
\text { No. } \\
\text { (figs. } \\
1-3)\end{array}$ & $\begin{array}{c}\text { USGS } \\
\text { Mesozoic } \\
\text { locality }\end{array}$ & $\begin{array}{c}\text { Collector's } \\
\text { field } \\
\text { No. }\end{array}$ & $\begin{array}{c}\text { Collector, year of collection, } \\
\text { stratigraphic assignment, } \\
\text { description of locality }\end{array}$ \\
\hline 5 _--- & 31456 & F5-14 & _.
\end{tabular}
Formation, upper member, about $400 \mathrm{ft}(122 \mathrm{~m})$ below top. Near USGS Mesozoic loc. 27368 in $\mathrm{NW}^{1 / 4} \mathrm{SW}^{1 / 4}$ sec. 15 , T. 17 S., R. 28 E., Izee Quad., Grant County, Oreg.

6 _-_- $27369 \quad$ I58-8-28B ______- R. W. Imlay, 1958. Snowshoe Formation, upper member $85 \mathrm{ft}(26 \mathrm{~m})$ below top. East side of Rosebud Creek just east of old farmhouse in $\mathrm{NE}^{1 / 4} \mathrm{NE}^{1 / 4} \mathrm{NE}^{1 / 4}$ sec. 21 , T. 17 S., R. 28 E., Izee Quad., Grant County, Oreg.

7 _-_- $30933 \quad$ I75-8-25 _._...... R. W. Imlay, 1975. Snowshoe Formation, upper member, $165 \mathrm{ft}(50 \mathrm{~m})$ below top. SW $1 / 4 \mathrm{SE}^{1 / 4} \mathrm{SW}^{1 / 4}$ sec. 21 , T. 17 S., R. 28 E., Izee Quad., Grant County, Oreg.

8 ___- 29799 I69-7-15A ______ R. W. Imlay, 1969. Trowbridge Shale, near base. About $450 \mathrm{ft}(137 \mathrm{~m})$ south and $100 \mathrm{ft}(30 \mathrm{~m})$ east of NW cor. sec. 2, T. 19 S., R. 25 E., Delintment Lake Quad., Harney County, Oreg.

8 _-_- 29800 I69-7-15B __-_._ R. W. Imlay, 1969. Trowbridge Shale near base. About $500 \mathrm{ft}(152 \mathrm{~m})$ south and $20 \mathrm{ft}(6 \mathrm{~m})$ east of NW cor. sec. 2, T. 19 S., R. 25 E., Delintment Lake Quad., Harney County, Oreg.

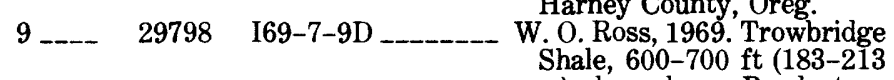
m) above base. Roadcut on west side of Warm Spring

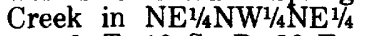
sec. 6, T. 19 S., R. 26 E., Delintment Lake Quad., Harney County, Oreg.

10

R. L. Lupher, 1930. Trowbridge Shale, estimated $1,000-1,250 \mathrm{ft}(305-380 \mathrm{~m})$ above base. On north side of Flat Creek above mouth of Spoon Creek and $200 \mathrm{ft}(61$ m) above creek level probably a little northeast of center of sec. 15, T. $18 \mathrm{~S}$., R. 27 E., Izee Quad., Grant County, Oreg.

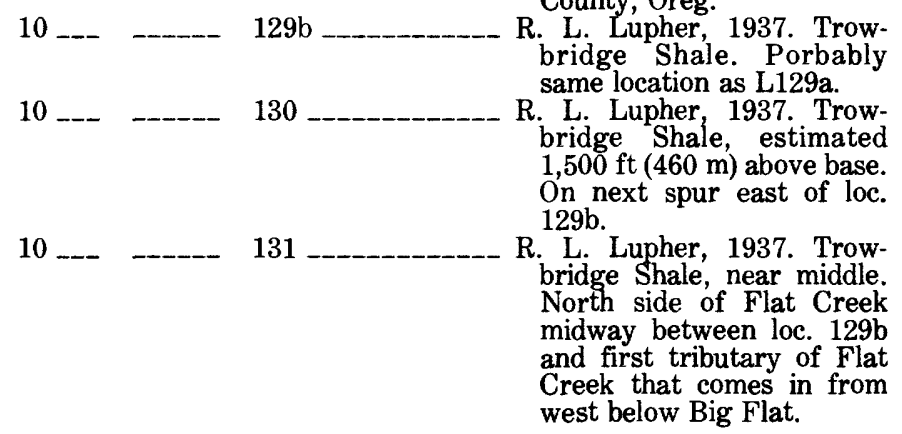

TABLE 6.-Description of Bathonian and Callovian ammonite localities in east-central Oregon and westernmost Idaho-Continued

\begin{tabular}{cccc}
\hline $\begin{array}{c}\text { Area } \\
\text { No. } \\
\text { figs. }\end{array}$ & $\begin{array}{c}\text { USGS } \\
\text { Mesozoic } \\
\text { locality } \\
\text { No. }\end{array}$ & $\begin{array}{c}\text { Collector's } \\
\text { field } \\
\text { No. }\end{array}$ & $\begin{array}{c}\text { Collector, year of collection, } \\
\text { stratigraphic assignment, } \\
\text { description of locality }\end{array}$ \\
\hline 10 - & 132 & $\begin{array}{c}\text { R. L. Lupher, 1937. Trow- } \\
\text { bridge Shale, lower middle } \\
\text { part, about 300 ft }(91 \mathrm{~m}) \\
\text { below green sandstone that } \\
\text { overlies concretionary } \\
\text { shale. Next gully northwest } \\
\text { from loc. 131. }\end{array}$ \\
10 & 139 & $\begin{array}{l}\text { R. L. Lupher, 1937. Trow- } \\
\text { bridge Shale. Near top of } \\
\text { shale exposures at either } \\
\text { loc. 131 or 132. }\end{array}$
\end{tabular}

10 _._ _ 5121 S. W. Muller, R. W. Imlay, W. R. Dickinson, L. W. Vigrass and John Beason, 1956. Trowbridge Shale, about $1,000 \mathrm{ft}(305 \mathrm{~m})$ above base On north slope of Flat Creek a little east of center of sec. 15, T. 18 S., R. $27 \mathrm{E}$., Izee Quad., Grant County,

10 _._ _-_ F122 _-___ W. R. Dickinson and others, 1956. Trowbridge Shale, about 1,250 ft (381 m) above base. A little northeast of loc. F121 in south-central part of $\mathrm{SW}^{1 / 4} \mathrm{NE}^{1 / 4}$ sec. 15 , T. 18 S., R. 27 E., Izee Quad., Grant County, Oreg.

11 ___ $29419 \quad$ I66-8-5 _____._ R. W. Imlay and W. O. Ross, 1966; Trowbridge Shale, probably near top. On ridge between Flat Creek and Jack Andy Creek in NE $\mathrm{NE}^{1 / 4}$ $\mathrm{SE}^{1 / 4} \mathrm{SW}^{1 / 4}$ sec. 16 , T. $18 \mathrm{~S}$., R. 31 E., Logdell Quad., Grant County, Oreg.

11 _-_ $29420 \quad$ I66-7-22B _.___- R. W. Imlay and W. O. Ross, 1966. Trowbridge Shale, probably near top. Conglomerate on low ridge about $300 \mathrm{ft}(91 \mathrm{~m})$ east of USGS Mesozoic loc. 29419 in $\mathrm{SW}^{1 / 4} \mathrm{SE}^{1 / 4}$ sec. $16, \mathrm{~T}$. 18 S., R. 31 E., Logdell Quad., Grant County, Oreg.

11 ___ 31454 Buddenhagen 85 _. H. J. Buddenhagen, 1959. Trowbridge Shale, about $3,100 \mathrm{ft}(945 \mathrm{~m})$ stratigraphically above sandstone unit that was mapped as top of Snowshoe Formation. On south side of Jack Andy Creek in $\mathrm{NW}^{1 / 4} \mathrm{SW}^{1 / 4}$ sec. 21, T. 18 S., R. 31 E., West Myrtle Butte Quad., Grant County, Oreg.

12 _.__ 28376 B-94 _-____-_ Marvin Beesoñ, R. L. Bateman, and R. W. Imlay, 1961. Shale probably in Trowbridge Shale. South side of road near junction of Bear Creek and a small tributary, in NW1/4 NW $1 / 4$ sec. 4, T. 19 S., R. 29 E. Sawtooth Creek Quad., Harney County, Oreg.

13 _-_ $28666 \quad$ B-87 _-_._- Marvin Beeson and R. L. Bateman, 1959 . Trowbridge
Shale, about $800 \mathrm{ft}(245 \mathrm{~m})$ 
TABLE 6. - Description of Bathonian and Callovian ammonite localities in east-central Oregon and westernmost Idaho-Continued

\begin{tabular}{ccc}
\hline Area & USGS & Collector's \\
No. & Mesozoic & field \\
(figs. & locality & No. \\
$1-3$ ) & No. & \\
\hline
\end{tabular}

14

15

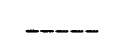

F124

15

15

27373 I58-9-1C

16

2678

DDV (4-82-20)

\section{County, Oreg.}

John Beeson, 1957. Lonesome

Formation, near middle. About 0.5 mile $(0.8 \mathrm{~km})$ south of Flat Creek in $\mathrm{SW}^{1 / 4}$ sec. 18 , T. 18 S., R. 28 E., Izee Quad., Grant County, Oreg.

17 _-_ 31411 Buddenhagen 148 _ H. J.' Buddenhagen, 1967. Lonesome Formation, $1,250-1,300 \mathrm{ft} .(381-396 \mathrm{~m})$ above base. From mudstone bed below thin sandstone bed on treeless southeastfacing slope about $350 \mathrm{ft}$ $(107 \mathrm{~m})$ northwest of Alder Creek, in $\mathrm{NE}^{1 / 4} \mathrm{SW}^{1 / 4}$ sec. 25, T. 18 S., R. 27 E., Sawtooth Creek Quad., Grant County, Oreg.
TABLE 6.-Description of Bathonian and Callovian ammonite localities in east-central Oregon and westernmost Idaho-Continued

\begin{tabular}{|c|c|c|c|}
\hline $\begin{array}{l}\text { Area } \\
\text { No. } \\
\text { (figs. } \\
1-3)\end{array}$ & $\begin{array}{c}\text { USGS } \\
\text { Mesozoic } \\
\text { locality } \\
\text { No. }\end{array}$ & $\begin{array}{l}\text { Collector's } \\
\text { field } \\
\text { No. }\end{array}$ & $\begin{array}{l}\text { Collector, year of collection, } \\
\text { stratigraphic assignment, } \\
\text { description of locality }\end{array}$ \\
\hline
\end{tabular}

17 __- 31412 Buddenhagen 149 _ H. J. Buddenhagen, 1967. Lonesome Formation, from float about $600 \mathrm{ft}(183 \mathrm{~m})$ above base. On ridge top about $650 \mathrm{ft}(198 \mathrm{~m}) \mathrm{N}$ $10^{\circ} \mathrm{W}$. of SE cor. $\mathrm{SE}^{1 / 4} \mathrm{sec}$. 25, T. 18 S., R. 27 E., Sawtooth Creek Quad., Grant County, Oreg.

17 _._ 31413 Buddenhagen 150 _ H. J. Buddenhagen, 1967 Lonesome Formation. Float probably from a higher stratigraphic position than USGS Mesozoic loc. 31411. Collected on a tractor road about $1,350 \mathrm{ft}(412 \mathrm{~m})$ west of NE cor. NE $1 / 4$ sec. 36 , T 18 S., R. 27 E. Sawtooth Creek Quad., Grant County Oreg.

18 _-_ 28667 No field number _._- Marvin Beeson, 1959. Lonesome Formation, about $10,000 \mathrm{ft}(3,050 \mathrm{~m})$ above base. On road from Sawtooth Creek to Yellowjacket Creek in SE cor. sec. 25, T. 19 S., R. 28 E., Sawtooth Creek Quad., Harney County, Oreg.

18 _-_ 29421 I66-7-31A _____. R. W. Imlay and Wm. O. Ross, 1966. Lonesome Formation, about $10,000 \mathrm{ft}(3,050 \mathrm{~m})$ above base. Roadcut about 0.25 mile $(0.4 \mathrm{~km})$ west of Yellowjacket Creek, SE $1 / 4$ SW $1 / 4$ sec. 30 , T. 19 S., R. 29 E., Sawtooth Creek Quad., Harney County, Oreg.

19 _-_ 30143 29593B _ Standard Oil Company of California, 1970. Lonesome Formation, about $500 \mathrm{ft}$ $(152 \mathrm{~m})$ above base. NE cor. $\mathrm{SE}^{1 / 4}$ sec. 28 , T. 20 S., R. 28 E., Sawtooth Creek Quad., Harney County, Oreg.

20 _31455 Buddenhagen 86 H. J. Buddenhagen, 1960 Lonesome Formation, probably about $3,000 \mathrm{ft}(915 \mathrm{~m})$ above base in $\mathrm{NE}^{1 / 4} \mathrm{SW}^{1 / 4}$ sec. 11 , T. 20 S., R. 28 E. Sawtooth Creek Quad. Harney County, Oreg.

21 T. L. Vallier and H. C. Brooks, 1968. Black shale and brown graywacke on Oregon side of Snake River near Pittsburg Landing, Idaho, altitude $1,450 \mathrm{ft}(442 \mathrm{~m}), \mathrm{NW}^{1 / 4}$ $\mathrm{NW}^{1 / 4} \mathrm{SW}^{1 / 4}$ sec. 28 , T. 2 N. R. 51 E., Grave Point Quad., Wallowa County,

R. W. Imlay and H. C. Brooks 1962. Black shale from roadcut on North Fork of Dennett Creek just below abandoned mining town of Mineral, near center SW1/4$\mathrm{NW}^{1 / 4}$ sec. 9 , T. 14 N., R. 6 W., Mineral Quad., Washington County, Idaho. 
TABLE 6.-Description of Bathonion and Callovian ammonite localities in east-central Oregon and westernmost Idaho-Continued

\begin{tabular}{|c|c|c|c|}
\hline $\begin{array}{l}\text { Area } \\
\text { No. } \\
\text { (figs. } \\
1-3 \text { ) }\end{array}$ & $\begin{array}{l}\text { USGS } \\
\text { Mesozoic } \\
\text { locality }\end{array}$ & $\begin{array}{l}\text { Collector's } \\
\text { field } \\
\text { No. }\end{array}$ & $\begin{array}{l}\text { Collector, year of collection, } \\
\text { stratigraphic assignment, } \\
\text { description of locality }\end{array}$ \\
\hline $23 \ldots$ & ----- & Livingstone 88 & $\begin{array}{l}\text { D. C. Livingstone, prior to } \\
1932 \text {. Black shale in canvon } \\
\text { of Dennett Creek near Min- } \\
\text { eral, Washington County, } \\
\text { Idaho. }\end{array}$ \\
\hline 24 & 30082 & & $\begin{array}{l}\text { Gabriel Paris, 1968. Black } \\
\text { shale containing limestone } \\
\text { nodules exposed in roadcut } \\
\text { extending from gypsum } \\
\text { mine to highest part of } \\
\text { ridge. About } 0.37 \text { mile }(0.59 \\
\text { km) N. 82 E. of Tate's } \\
\text { cabin near Dennett Creek, } \\
\text { NE1/4 NE } 1 / 4^{1 / 4} \text { sec. 9, T. 14 N., } \\
\text { R. 6 W., Mineral Quad., } \\
\text { Washington County, Idaho. }\end{array}$ \\
\hline $25 \ldots$ & - & Hendrickson & $\begin{array}{l}\text { Tom Hendrickson, } 1972 . \\
\text { Black shale in NW'1/4NW1/4 } \\
\text { sec. 10, T. } 14 \text { N., R. } 6 \text { W., } \\
\text { Mineral Quad., Washington } \\
\text { County, Idaho. }\end{array}$ \\
\hline
\end{tabular}

\section{SYSTEMATIC DESCRIPTIONS}

Family SPIROCERATIDAE Hyatt, 1900

Genus PARAPATOCERAS Spath, 1924

Parapatoceras sp.

Plate 1, figure 1

One laterally crushed external mold of the adoral part of an uncoiled ammonite bears ornamentation similar to that on Spiroceras and Parapatoceras. Its flank ribs are low, fairly narrow, rather closely spaced, incline considerably forward, become a little stronger ventrally, and terminate ventrally in fairly prominent conical tubercles. In addition, a row of weak tubercles occurs on the ribs high on the flanks. The venter is not preserved.

This specimen has ribs similar to those on Parapatoceras distans var. densicostatum (Quenstedt) (1886, p. 581, pl. 70, fig. 19; Potonie, 1929, p. 254, pl. 19, fig. 59) in density and in forward inclination but appears to have somewhat stronger ventral tubercles. The ribs appear to be weaker and lower than on densely ribbed species of Spiroceras, such as S. annulatum (Deshayes) from eastern Oregon (Imlay, 1973, p. 55, pl. 1, figs. 9-16). Assignment of the specimen to Parapatoceras rather than Spiroceras is favored by its association with Xenocephalites of late Bathonian to early Callovian Age, whereas Spiroceras is of late Bajocian age.

Figured specimen. - USNM 248071.

Occurrence. - Trowbridge Shale, near base at USGS Mesozoic loc. 29799.
Family TULITIDAE Buckman, 1921

Genus BULLATIMORPHITES Buckman, 1921

\author{
Bullatimorphites sp. \\ Plate 1, figures 2-5, 7
}

Bullatimorphites is represented in eastern Oregon by two small slightly crushed specimens on which only one side is preserved. Both specimens are microconchs, as shown by the presence on each of an apertural constriction. Their outer whorl appears to be nearly as high as wide. Their body chamber occupies about three-fourths of a whorl and is markedly contracted. One specimen bears a broad ventral collar that is not prefectly preserved but does not appear to be strongly flared.

Their ornamentation consists of thick, irregularly spaced ribs that trend radially on the lower part of the flank and irregularly in direction on the upper part of the flanks. Some of the ribs bifurcate low on the flanks, many bifurcate on the middle part of the flanks, and some remain simple. The secondary ribs are a little weaker than the primary ribs. One specimen bears somewhat stronger ribbing than the other.

The suture line is poorly preserved and cannot be traced.

These specimens differ from most microconchs of Bullatimorphites by being much smaller and less inflated. In size, coiling, ribbing, and apparently also in whorl shape they are similar to B. laurenti (Enay) (1959, p. 253,254 , pl. 7b, figs. 4a-c; Hahn, 1971, p. 108, pl. 8 , figs. 7a, b) and to B. crimaciense (Enay) $(1959$, p. 255 , pl. $7 \mathrm{~b}$, figs. 5a, b, 6a, b; Quenstedt, 1886, pl. 78, fig. 8). Both those species were placed in a new genus, Treptoceras, by Enay $(1959$, p. 253) but were considered by Hahn (1971, p. 106) to be merely compressed taxa of Bomburites (Arkell, 1952, p. 90; Grossouvre, 1891, p. 261, pl. 9 , figs. $6 \mathrm{a}-\mathrm{c}$ ) to which he assigned a subgeneric rank under Bullatimorphites.

The correct subgeneric assignment of the Oregon specimens of Bullatimorphites must await the discovery of adult specimens in which the ventral part of the adult apertural collar is well preserved. They cannot be assigned to either Bomburites or Treptoceras unless the ventral part of that collar is strongly flared.

Figured specimen.-248072, 248073.

Occurrence.-Snowshoe Formation, upper member, about 450 feet $(137 \mathrm{~m})$ below the top at USGS Mesozoic loc. 31457 . 
Family MACROCEPHALITIDAE Buckman, 1922

Genus XENOCEPHALITES Spath, 1928

Xenocephalites vicarius Imlay

Plate 1, figures 6, 8-18

Xenocephalites vicarius Imlay, 1953, U.S. Geological Survey Professional Paper 249-B, p. 78, pl. 28, figs. 1-8.

Xenocephalites vicarius Imlay, 1964, U.S. Geological Survey Professional Paper 483-D, p. D14, pl. 1, figs. 23-27.

The characteristics of this species have been summarized by Imlay $(1964$, p. D14). The species is represented in the Izee-Seneca area in eastern Oregon by about 45 specimens, near Pittsburg Landing on the Snake River in easternmost Oregon by 20 specimens, and near Mineral, Idaho, by 4 specimens.

Hypotypes. - USNM 248074-248078.

Occurrences.-Lonesome Formation at Dickinson's loc. F124; Trowbridge Shale at USGS Mesozoic locs. 28376, 29419, 29420, 29798, and 29799; upper member of Snowshoe Formation at USGS Mesozoic locs. 26778, 30403, and 31456; unnamed beds at Pittsburg Landing on the Snake River at Mesozoic loc. 29771; unnamed beds near Mineral, Idaho, at Livingston's loc. 88. The species ranges through the upper 600 feet $(183 \mathrm{~m})$ of the Snowshoe Formation, all of the Trowbridge Shale, and the lower 7,000 feet $(2,134 \mathrm{~m})$ of the Lonesome Formation.

\section{Genus LILLOETTIA Crickmay, 1930}

Lilloettia stantoni Imlay

Plate 1, figues 20-26

Lilloettia stantoni Imlay, 1953, U.S. Geological Survey Professional Paper 249-B, p. 77, pl. 29, figs. 1-5, 9, 10.

Lilloettia cf. L. stantoni Imlay, 1964, U.S. Geological Survey Proffessional Paper 483-D, p. D14, pl. 2, figs. 13, 16.

The presence of $L$. stantoni in eastern Oregon has been confirmed now at three localities.

Hypotypes.-USNM 132365, 248079, 248080, 252631-252633.

Occurrences. - Trowbridge Shale at USGS Mesozoic locs. 28376 and 29798; unnamed beds at USGS Mesozoic loc. 29771 on Oregon side of Snake River at Pittsburg Landing.

\section{Family KOSMOCERATIDAE Hang, 1887 \\ Genus KEPPLERITES Neumayr and Uhlig, 1892}

Kepplerites snugharborensis (Imlay)

Plate 2, figures 1,2

Gowericeras snugharborensis Imlay, 1953, U.S. Geological Survey Professional Paper 249-B, p. 99, pl. 53, fig. 9.

The holotype is characterized by a rather stout ovate whorl section, a moderately wide umbilicus; moderately strong primary ribs that incline slightly forward on the lower third of the flank and terminate in small conical tubercles; and fine, closely spaced secondary ribs that outnumber the primary ribs about 3.5 to 1 . The species is now considered to include an Alaskan specimen that has slightly weaker ribbing and was originally described as Gowericeras sp. (Imlay, 1953, p. 100, pl. 53, figs. 6, 7, 10).

The species is represented at one locality in western Idaho by three specimens. Of these, the smallest bears ribbing similar to that on the holotype of $K$. snugharborensis (Imlay). The largest specimen, herein figured, has similar ribbing that becomes a little finer and denser adorally.

In Alaska, $K$. snugharborensis was collected near the base of the Chinitna Formation within a sequence characterized by Iniskinites intermedius (Imlay) (Imlay, 1953 , p. $65 ; 1975$, p. 4,6$)$. In western Idaho, the species was collected with Lilloettia buckmani (Crickmay), a genus that in eastern Oregon is not known below the Trowbridge Shale and in Alaska is not known below the Chinitna Formation.

Hypotypes. - USNM 252634.

Occurrence. - Unnamed beds near Mineral, Idaho, at USGS Mesozoic loc. 30082.

\section{Kepplerites cf. K. plenus (McLearn)}

Plate 2, figure 9

One large laterally crushed ammonite from the Izee area of eastern Oregon is represented by three whorls, of which the inner two are mostly septate and the outer is nonseptate. The ornamentation on the middle whorl is similar to that on the outermost septate whorl and on the adapical end of the body chamber of Kepplerites plenus (McLearn) (McLearn, 1927, pl. 1, fig. 1; 1929, pl. 1; Imlay 1953, p. 99, pl. 49, fig. 21). The outer whorl of the Oregon specimen bears much coarser ornamentation than do those of the illustrated specimens of $K$. plenus just mentioned, but it is much larger and could represent that adult body chamber of the same species.

Figured specimen.-USNM 252635.

Occurrence. - Snowshoe Formation about $550 \mathrm{ft}$ (168 m) stratigraphically below the top of the upper member at USGS Mesozoic loc. 31407.

\section{Kepplerites sp. \\ Plate 2, figures 12, 13}

This species is represented by two laterally compressed specimens. It has a subovate whorl section that is higher than wide, an evenly rounded venter, a fairly wide umbilicus, and evolute coiling that becomes more evolute during growth. Its umbilical wall is low, nearly vertical, and rounds evenly into the flank.

Its ribs curve backward on the umbilical wall, incline gently forward on the flanks, and cross the venter transversely. Its primary ribs are sharp, moderately spaced, and terminate in fairly sharp tubercles at about two-fifth of the height of the flanks. From these tubercles pass pairs of weaker secondary ribs. Most rib 
pairs are separated by single ribs that arise freely along the zone of tuberculation. The suture line cannot be traced.

The species shows some resemblance to Kepplerites lindgreni Hyatt from California (Crickmay, 1933, p. 57, pl. 17, figs. 9, 10; Imlay, 1961, p. D-20, pl. 1, figs. 12, 14) and to a similar species from southern Alaska (Imlay, 1961, pl. 1, fig. 13), but it differs from both by having fewer secondary ribs per primary rib.

Figured specimens. - USNM 252636 and 252664.

Occurrence.-Trowbridge Shale at USGS Mesozoic loc. 31454 . This occurrence is about 3,100 feet $(945 \mathrm{~m})$ above a massive sandstone unit about 700 feet $(213 \mathrm{~m})$ thick, whose uppermost beds about 3 miles $(4.8 \mathrm{~km})$ to the southwest, near the center of sec. 36 . T.18 S., R. 30 E., have furnished Chondroceras? sp. of probable Bajocian Age.

\section{Genus TORRICELLICERAS Buckman, 1922}

Torricelliceras izeeensis Imlay, $n$. sp.

Plate 3, figures 6-10

This species is represented by one much-weathered septate specimen whose inner whorls are well preserved and by one adult specimen, of which only one side and part of the venter is exposed. On the small inner whorls (pl. 3, figs. 7-10), the whorl section is depressed ovate; the umbilicus is moderate in width; the umbilical wall is moderate in height, is vertical at its base, and rounds evenly above into low, fairly flat flanks. During growth, the umbilicus gradually becomes fairly wide and the whorl section higher. On the adult specimen, the body chamber is ovate and is apparently as high as wide. The body chamber is completely preserved, bears a lateral lappet, and occupies about three-fourths of a whorl. It is broken at its adapical end by a small fault and as a result has moved slightly ventrally with respect to the penultimate whorl. The venter appears to be evenly rounded.

The innermost preserved septate whorls bear sharp, fairly widely spaced primary ribs that curve slightly forward and terminate in tubercles just below the line of involution, which is near the widest part of the whorl. From the tubercles pass pairs of slightly weaker ribs that cross the venter transversely and are weakly sulcate along the midline of the venter.

Adorally on larger septate whorls and on the body whorl, the primary ribs gradually become stronger and sharper, curve strongly forward near the aperture, and terminate in small conical tubercles at about two-fifths the height of the flanks.

Adorally on the larger septate whorls, the secondary ribs gradually become much finer than the primary ribs, branch from the lateral tubercles by twos, or rarely by threes, or arise singly between branched ribs, and out- number the primary ribs three to one. All these secondary ribs incline forward on the flanks but apparently cross the venter transversely.

The secondary ribs on the adult body chamber become stronger, sharper, and sparser adorally, arise in pairs or singly from the tubercles, or rarely arise singly between the tubercles, and outnumber the primary ribs two to one.

The holotype at a diameter of $109 \mathrm{~mm}$ has a whorl height of $35 \mathrm{~mm}$ and an umbilical width of $51 \mathrm{~mm}$. The innermost whorl (pl. 3, figs 8-10) of the paratype at a diameter of $17 \mathrm{~mm}$ has a whorl height of $6 \mathrm{~mm}$, a whorl thickness of $9.5 \mathrm{~mm}$, and an umbilical width of $6.5 \mathrm{~mm}$.

This species bears considerable resemblance to Torricelliceras spinosus (Imlay) (1953, p. 99, pl. 53, figs. 8, 11) but is more evolute, has much weaker ribs and tubercles, has fewer secondary ribs per primary rib on its adult body chamber, and apparently has a more compressed whorl section. It is more evolute than $T$. newcombii (Whiteaves) (McLearn, 1929, p. 12, pl. 5, figs. 2-4) and has more secondary ribs per primary rib except on its body chamber. T. approximatum (Buckman) (1922, pl. 336) has similar ribbing on its adult body chamber and much coarser ribbing on its septate whorls.

Types.-Holotype USNM 252637; paratype USNM 252638 .

Occurrence.-Snowshoe Formation, upper member, about $580 \mathrm{ft}(177 \mathrm{~m})$ below the top at USGS Mesozoic loc. 31408; about $450 \mathrm{ft}(137 \mathrm{~m})$ below top at USGS Mesozoic loc. 31457.

Torricelliceras cf. T. spinosus (Imlay)

Plate 3, figure 5

One small fragment bears ribs and tubercles similar to those on the outer whorl of $T$. spinosus (Imlay) (1953, p. 99, pl. 53, figs. 8, 11; this report, pl. 3, figs. 1-4) from the Iniskin Peninsula west of Cook Inlet, Alaska, but differs by having shorter and more prominent primary ribs. The Alaskan species occurs a little below the middle of the Tonnie Siltstone Member of the Chinitna Formation (Imlay, 1975, p. 5, 6) in association with Cadoceras and Pseudocadoceras grewingki (Pompeckj) and a little above the range of Iniskinites. In contrast, the Oregon specimen was collected within the range of Iniskinites and considerably below the beds containing Pseudocadoceras.

Figured specimen. -USNM 252639.

Occurrence. - Upper Member of Snowshoe Formation, about 150 feet $(48 \mathrm{~m})$ below its top at USGS Mesozoic loc. 26778 . 
Family CARDIOCERATIDAE Siemiradzki, 1891

Genus PSEUDOCADOCERAS Buckman, 1918

Pseudocadoceras grewingki (Pompeckj)

Plate 2, figures 3-8

For synonymy and description see Imlay, 1953, p. 93.

This species is represented in eastern Oregon by at least 120 molds, of which the best preserved are from USGS Mesozoic loc. 29421. It has a narrowly rounded venter, a fairly wide umbilicus, and strong sharp ribs that coarsen adorally, incline forward on the venter, and bifurcate fairly regularly a little below the middle of the flanks. On the body whorl, the secondary ribs tend to be loosely united with the primary ribs, and some primary ribs remain unbranched.

Hypotypes. - USNM 252640-252644.

Occurrence. - Lonesome Formation at USGS Mesozoic locs. 26780 and 29421, which are respectively near the middle and top of the formation. $P$. cf. $P$. grewingki (Pompeckj) occurs at USGS Mesozoic locs. 30143, 31455 , and 28667 at positions ranging from 500 to 10,000 feet $(152$ to $3,049 \mathrm{~m})$ above the base of the Lonesome Formation.

\section{Genus INISKINITES Imlay, 1975}

Iniskinites acuticostatus Imlay, n. sp.

Plate 4, figures 3-14

This species is represented by 21 specimens, of which two are adults. The whorl section is ovate, a little higher than wide, and widest on the lower fourth of the flanks. The umbilicus is extremely narrow but opens slightly near the aperture of the adult body chamber. The umbilical wall is low, vertical at base, and rounds evenly into the flanks. The flanks are gently convex and merge into an evenly rounded venter. The body chamber occupies about three-fourths of a whorl and apparently becomes a little higher adorally. The aperture is marked by a shallow, forwardly inclined constriction, as exposed on the lower part of the flank on one specimen.

The ribs on the septate whorls are high, sharp, moderately spaced, and become stronger ventrally and adorally. They arise on the umbilical wall, incline gently forward on the lower part of the flanks, recurve slightly at about the top of the lower third of the flanks, and then cross the venter transversely. Most ribs bifurcate between the lower fourth and lower third of the flanks, but some remain simple and alternate with single ribs that arise along the zone of rib furcation.

The ribs on the body chamber are sharp and high where the shell is preserved and gradually become more widely spaced. Unforked primary ribs become common adorally. Some short ribs arise between simple or forked primary ribs. The zone of rib furcation gradually rises adorally to a little above the middle of the flanks. This ribbing persists to near the aperture without reduction in strength.

The suture line is poorly preserved and cannot be traced accurately.

The holotype at a diameter of about $105 \mathrm{~mm}$ has a whorl height of $50 \mathrm{~mm}$, an estimated whorl thickness of $46 \mathrm{~mm}$, and an umbilical width of $9 \mathrm{~mm}$. At a diameter of about $80 \mathrm{~mm}$, the whorl height is about $45 \mathrm{~mm}$, the estimated whorl thickness is $36 \mathrm{~mm}$, and the umbilical width is $7 \mathrm{~mm}$. One small paratype (pl. 4, figs. 3-5) at a diameter of 57 has a whorl height of $30 \mathrm{~mm}$ and a whorl thickness of $27 \mathrm{~mm}$.

This species is more compressed than any other described species of Iniskinites. Its features are most similar to those of I. intermedius (Imlay) (1953, p. 81, pl. 31 , figs. $1-4$, pl. 32 , figs. $2,3,5,7,8 ; 1975$, p. 24 , pl. 3 , figs. 3,4 ), from which it differs by having a more compressed whorl section and sharper, higher, and sparser ribbing.

Types. - Holotype, USNM 252645; paratypes, USNM $252646-252653$.

Occurrences. - Upper member of the Snowshoe Formation at USGS Mesozoic locs. 26778, 30401, 31408, and 31410 in eastern Oregon. On the basis of these occurrences, $I$. acuticostatus occurs from 110 to 600 feet (33 to $183 \mathrm{~m}$ ) below the top of the Snowshoe Formation. The species is probably represented also by many small immature specimens at USGS Mesozoic locs. 30403, 30404, 30406, and 30933.

\section{Iniskinites cf. I. intermedius (Imlay) \\ Plate 1, figure 19}

One partly crushed and much worn adult body chamber bears fine, fairly closely spaced ribbing, which is identical with that on I. intermedius (Imlay) (1953, pl. 31 , figs. $1-4$, pl. 32 , figs., $2,3,5,7,8 ; 1975$, pl. 3, figs. 3 , 4) and which is much finer and sparser than that on specimens of $I$. acuticostatus Imlay $\mathrm{n}$. sp., which are described herein. The smoothness of the venter on the adoral third of the body chamber is due to weathering.

Figured specimen. - USNM 252654.

Occurrence. - Snowshoe Formation, upper member, at USGS Mesozoic loc. 31409 about 600 feet $(183 \mathrm{~m})$ below the top of the formation.

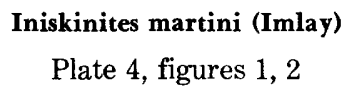

Kheraiceras martini Imlay, 1953, U.S. Geological Survey Professional Paper 249-B, p. 80, pl. 32, figs. 1, 4, 6.

Iniskinites martini (Imlay), 1975, U.S. Geological Survey Professional Paper 836, p. 24, pl. 4, figs. 1, 3-6.

This species differs from $I$. intermedius (Imlay) by being much stouter and somewhat larger.

Hypotype. - USNM 252655.

Occurrence. - Upper member of Snowshoe Formation 
at USGS Mesozoic loc. 30931, eastern Oregon. Its occurrence is about 640 feet $(195 \mathrm{~m})$ below the top of the member.

\section{Family PERISPHINCTIDAE Steinmann, 1890 \\ Genus COBBANITES Imlay, 1962 \\ Cobbanites ochocoensis Imlay, n. sp. Plate 5, figures 1, 4-8}

Cobbanites aff. C. talkeetnanus Imlay, 1964, U.S. Geological Survey Professional Paper 483-D, p. D16, pl. 4, figs. 10-13.

Nine specimens from the Snowshoe Formation in eastern Oregon differ from C. talkeetnanus Imlay in southern Alaska by having a lower, broader whorl section and coarser ribs that are more closely spaced on the inner septate whorls and much more widely spaced on the outer septate whorls. The adult body whorl becomes smooth as in C. talkeetnanus Imlay (1962, p. C 27, pl. 8, fig. 1).

Types. - Holotype, USNM 252656; paratypes, USNM 252657-252660, 132371a, and 132371b.

Occurrences. - Snowshoe Formation, upper member, from 85 to 700 feet ( 26 to $213 \mathrm{~m}$ ) below the top at USGS Mesozoic locs. 26778, 27369, 30402, 30404, 30405, 30406 , and 30408 .

\section{Genus CHOFFATIA Siemiradzki, 1898 Choffatia? sp.}

Plate 2, figures 10,11

One immature ammonite represents parts of three whorls. Its umbilicus is fairly wide. Its outer whorl is subovate and a little higher than wide. Its umbilical wall is low and steeply inclined. Its flanks are fairly flat. The innermost preserved whorl bears strong, radially trending primary ribs and one constriction. The next larger whorl bears slightly stronger radial ribs, one of which bifurcates near the middle of the exposed flanks. The outermost whorl bears moderately spaced primary ribs that are strongest on the umbilical wall and on the lower half of the flanks. Some primary ribs remain simple, but most bifurcate between the middle and upper third of the flanks into much weaker secondary ribs. One primary rib bifurcates near the middle of the lower third of the flanks, and resulting secondary ribs fork again near the middle of the flanks. All secondary ribs trend nearly radially on the flanks, cross the venter transversely, and become weaker but sharper on the venter. Some secondary ribs arise freely near or a little above the middle of the flanks.

This specimen is assigned to Choffatia rather than to Procerites because of its fairly evolute coiling and the presence of constrictions and because its primary ribs are somewhat stronger than its secondary ribs. Its preservation does not permit a positive generic determination.
Figured specimen.-USNM 252661.

Occurrence. - Trowbridge Shale, from 600 to 700 feet (183 to $213 \mathrm{~m}$ ) above base at USGS Mesozoic loc. 29798.

\section{Genus GROSSOUVRIA Siemiradzki, 1898}

\section{Grossouvria sp.}

Plate 5, figures 2, 3, 9

Two small, laterally crushed fragments of immature ammonites are characterized by evolute coiling; by a wide shallow umbilicus; by variably strong, variably spaced, partly forked ribs that incline forward on the flanks and in places curve backward on the venter; and by many constrictions. On the outermost preserved whorl, about half the ribs fork near the middle of the flanks. Simple and forked ribs may or may not alternate. Those features all favor an assignment to Grossouvria rather than to Siemiradzkia.

Figured specimen. - USNM 2526662 and 252663.

Occurrence. - Unnamed beds at Pittsburg Landing on west side of Snake River in Oregon at USGS Mesozoic loc. 29771.

\section{REFERENCES CITED}

Arkell, W. J., 1950-1958, Monograph of the English Bathonian ammonites: London, Palaeontographical Society, 8 v., 33 pls., 83 text-figs.

1956, Jurassic geology of the world: London, Oliver \& Boyd, 806 p., 46 pls., 102 figs.

Arkell, W. J., Kummel, Bernhard, and Wright, C. W., 1957, Mesozoic Ammonoidea, in Moore, R. C., ed., Treatise on invertebrate paleontology, Part L, Mollusca 4, Cephalopoda, Ammonoidea: New York and Lawrence, Kans., Geological Society of America and University of Kansas Press, p. L80-L437.

Buckman, S. S., 1909-1930, Type ammonites: London, privately published, 7 v. (v. 7 (1930), edited by A. M. Davis.)

Crickmay, C. H., 1933, Mount Jura investigation: Geological Society of American Bulletin, v. 44, no. 5, p. 895-926, pls. 23-34.

Detterman, R. L., and Hartsock, J. K., 1966, Geology of the Iniskin-Tuxedni region, Alaska: U.S. Geological Survey Professional Paper 512, 78 p., 6 pls., 7 figs.

Dickinson, W. R., 1962a, Metasomatic quartz keratophyre in central Oregon: American Journal of Science, v. 260, no. 4, p. 249-266, 6 figs.

$1962 \mathrm{~b}$, Petrology and diagenesis of Jurassic andesitic strata in central Oregon: American Journal of Science, v. 260, no. 7, p. 481-500, 6 figs.

Dickinson, W. R., and Vigrass, L. W., 1965, Geology of the SupleeIzee area, Crook, Grant and Harney Counties, Oregon: Oregon Department of Geology and Mineral Industries Bulletin 58, 109 p.

Enay, Raymond, 1959, Note sur quelques Tulitidés (Ammonitina) du Bathonian: Societé Géologique de France Bulletin, sér. 7, v. 1, no. 3 , p. 252-258, pl. $7 \mathrm{~b}$.

Grossouvre, A. de, 1891, Sur le Callovien de l'ouest de la France et sur sa faune: Societé Géologique de France Bulletin [3d ser.], v. 19 , p. 247-262, pl. 9

Hahn, Wolfgang, 1971, Die Tulitidae S. Buckman, Sphaeroceratidae S. Buckman und Clydoniceratidae S. Buckman (Ammonoidea) des Bathoniums (Brauner Jura $\epsilon$ ) im südwestdeutschen Jura: 
Baden-Württemberg Geologisches Landesamt Jahreshefte, v. 13 , p. 55-122, 13 figs.

Imlay, R. W., 1953, Callovian (Jurassic) ammonites from the United States and Alaska-Part 2. Alaska Peninsula and Cook Inlet regions: U.S. Geological Survey Professional Paper 249-B, p. 41-108, pls. 25-55, figs. 3-9.

-1961, Late Jurassic ammonites from the western Sierra Nevada, California: U.S. Geological Survey Professional Paper 374-D, 30 p., 6 pls., 3 figs.

1962, Jurassic (Bathonian or early Callovian) ammonites from Alaska and Montana: U.S. Geological Survey Professional Paper 374-C, 32 p., 8 pls., 7 figs.

1964, Upper Jurassic mollusks from eastern Oregon and western Idaho: U.S. Geological Survey Professional Paper 483-D, 21 p., 4 pls., 3 figs.

1968, Lower Jurassic (Pliensbachian and Toarcian) ammonites from eastern Oregon and California: U.S. Geological Survey Professional Paper 593-C, 51 p., 9 pls., 8 figs.

-1973, Middle Jurassic (Bajocian) ammonites from eastern Oregon: U.S. Geological Survey Professional Paper 756, 100 p., 47 pls., 8 figs.

-1975, Stratigraphic distribution and zonation of Jurassic (Callovian) ammonites in southern Alaska: U.S. Geological Survey Professional Paper 836, 28 p., 6 pls., 9 figs.

1979, Middle Jurassic (Bathonian) ammonites from southern
Alaska: U.S. Geological Survey Professional Paper 1091, 42 p., 12 pls., 11 figs.

Imlay, R. W., and Detterman, R. L., 1973, Jurassic paleobiogeography of Alaska: U.S. Geological Survey Professional Paper 801, 34 p., 15 figs.

1977, Some Lower and Middle Jurassic beds in Puale BayAlinchak Bay area, Alaska Peninsula: American Association of Petroleum Geologists Bulletin, v. 61, no. 4, p. 607-611, 2 figs.

Livingston, D. C., 1932, A major overthrust in western Idaho and northeastern Oregon: Northwest Science, v. 6, no. 2, p. 31-36.

McLearn, F. H., 1927, Some Canadian Jurassic faunas: Royal Society of Canada Transactions, 3d ser., v. 21, sec. 4, p. 61-73, pl. 1. 1929, Contributions to the stratigraphy and paleontology of Skidegate Inlet, Queen Charlotte Islands, British Columbia: Canada National Museum Bulletin 54, p. 1-27, 16 pls.

Potonie, Robert, 1929, Die ammonitischen Nebenformen des Dogger (Apsorroceras, Spiroceras, Parapatoceras): Preussische Geologische Landesanstalt Jahrbuch, v. 50, pt. 1, p. 216-261, pls. 17-19.

Quenstedt, F. A. von, 1886-87, Die Ammoniten des Schwäbischen Jura, v. 2, Der Braune Jura: Stuttgart, E. Schweizerbart, p. 441-672, pls. 55-78 (1886); p. 673-815, pls. 79-90 (1887).

Vallier, T. L., 1968, Reconnaissance geology of the Snake River Canyon between Granite Creek and Pittsburg Landing, Oregon and Idaho: Ore Bin, v. 30, no. 12, p. 233-252, 12 figs. 


\section{INDEX}

[Italic page numbers indicate major references]

acuticostatus, Iniskinites

Alaska, southe

Alaska Peninsula

Alder Creek, Oreg

Ammonite faunal setting

annulatum, Spiroceras

approximatum, Torricelliceras

Basey Member, Snowshoe Formation

Bear Creek, Oreg

Bibliography

Big Flat, Oreg

Biologic analysis

Bomburites

Page

rermation

buckmani, Lilloettia

Bullatimorphites

crimaciense

laurenti

$9,10,20 ; \mathrm{pl}, 4$ $5,7,9,10,11,12$

$$
\mathrm{sp}
$$

9,$17 ; \mathrm{pl} .1$

Cadoceras

$7,9,10,11,19$

catostoma zone

Cadoceratinae

Calliphylloceras

$$
\text { sp }
$$

Calliphylloceratinae

Cardioceratidae

catostoma, Cadoceras, zone 10

cerealis, Choffatia

Chinitna Formation _. $5,7,9,10,11$

Chinitnites 10

Choffatia _.___________________ 2, $7,10,13,21$

cerealis

$$
\text { sp - }
$$

Cobbanites

$2,7,9,10,13,2$ ochocoensis _________ 9, $21 ; \mathrm{pl} .5$ talkeetnanus

12,21

Cook Inlet, Alaska

costidensus, Cranocephalites ____ 9,10

Cranocephalites

costidensus

culebra, Gryphaea

D

Delintment Lake, Oreg

densicostatum, Parapatoceras distans

$-11$

distans densicostatum, Parapatoceras

\section{E}

Emigrant Creek, Oreg

Erycitoides

Eudmetoceras

Flat Creek, Oreg 4,11

Formations, ages and correlations of

Fossil collections, nature of
G

Geographic distribution

Grant County, Oreg _. 7

grewingki, Pseudocadoceras _._._.___ 11, 12, 19, 20; pl. 2

Grossouvria $2,13,21$$$
\mathrm{sp}
$$

12,$21 ; \mathrm{pl} .5$

Gryphaea culebra

$\mathrm{H}$

Harney County, Oreg

hickersonensis, Parareineckein $-7$

\section{I}

Iniskin Bay, Alaska

Iniskinites

acuticostatus

intermedius$$
\text { one }
$$

martini

ne$$
\text { sp }
$$

ermedius, Iniskinites

$$
\text { zone }
$$

Introduction

izeeensis, Torricelliceras

Jack Andy Creek, Oreg

John Day River, Oreg

\section{K}

Kepplerites lindgreni 19 plenus _. snugharborensis _...____ 12, 18; pl. 2

torrensi ____ 9, $9,11,12$

$\mathrm{sp}$

Kheraiceras martini

Kosmoceratidae 2

L

laurenti, Bullatimorphites

Leptosphinctes

Leptosphinctinae

Lewis Creek, Oreg

Lilloettia

$7,10,11,12,19,20$ , $10,18,20 ; \mathrm{pl} .4$

buckmani

mertonyarwoodi _..._. 12

stantoni

$11,12,18 ; \mathrm{pl} .1$

sp -

lindgreni, Kepplerites
Lonesome Formation

$\begin{array}{lr}\text { Lonesome Formation } & 3,7,11 \\ \text { Lytoceras } & \end{array}$$$
\text { sp }
$$

Lytoceratidae

\section{M}

Macrocephalites macroephalus zone

Macroecephalitidae

macroephalus, Macrocephalites, zone _._._.___._. 9

martini, Iniskinites

9,$20 ; \mathrm{pl} .4$

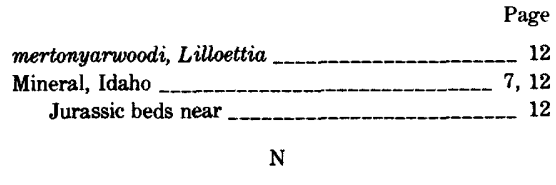

newcombii, Torricelliceras 19

o

ochocoensis, Cobbanites 9,21; pl. 5

$\mathbf{P}$

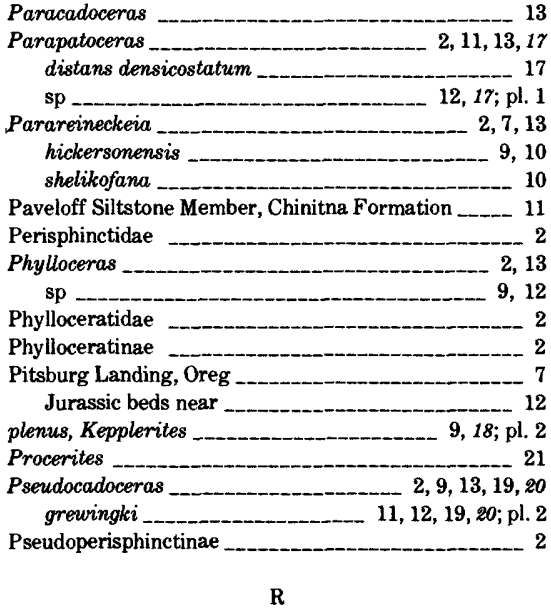

Reineckeiidae 2

S

Seimiradzkia

Shelikof Formation

21 sheikofana, Parareineckeia _.______________ 10

Silvies Member, Snowshoe Formation

Snake River ________________________ 12

Snake River Canyon area

Snowshoe Formation ___________ 1, 3, 4, 5, 10,12

snugharborensis, Gowericeras _____ 18

Kepplerites ______ 12, 18; pl. 2 spinosus, Torricelliceras ___ 9, 19; pl. 3

Spiroceras annulatum ___________ 17

Spiroceratidae -__ 2

stantoni, Lilloettia _

Stenocadoceras _...... 13

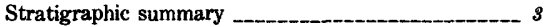

T

Talkeetna Mountains, Alaska

talkeetnanus, Cobbanites

Tmetoceras _-___ 7

Tonnie Siltstone Member, Chinitna Formation - 9, 10,12

torrensi, Kepplerites ___________ 9, 11, 12

Torricelliceras _._ $2,7,13,19$ approximatum ___ 19 izeeensis _-_ 9,$19 ; \mathrm{pl} 3$

newcombii _____________________________ 19

spinosus ___ 9,$19 ; \mathrm{pl} 3$ 
INDEX

\begin{tabular}{rr} 
& P \\
vicarius, Xenocephalites & \\
\hline W & $9,10,11,12,18$; pl. 1
\end{tabular}

Wide Bay, Alaska

10
Trowbridge Shale

Tulitidae _- 5,12
$\mathrm{X}$

Xenocephalites $2,7,10,12,13,17,18$ vicarius ____- $9,10,11,12,18$; pl. 1 page

sp _-_




\section{PLATES 1-5}

Contact photographs of the plates in this report are available, at cost, from U.S. Geological Survey

Library, Federal Center, Denver, Colorado 80225 


\section{PLATE 1}

[Figures natural size unless otherwise indicated]

FiguRE 1. Parapatoceras sp. (p. 13).

Specimen, USNM 248071 from USGS Mesozoic loc. 29799.

2-5, 7. Bullatimorphites sp. (p. 17).

2-5. Ventral and lateral views of specimen, USNM 248072 from USGS Mesozoic loc. 31457. Note that figures 1 and 2 are ( $\times 2)$. 7. Lateral view $(\times 2)$ of specimen, USNM 248073 from USGS Mesozoic loc. 31457.

6, 8-18. Xenocephalites vicarius Imlay (p. 18)

6, 16. Lateral and ventral views of hypotypes, USNM 248076 from USGS Mesozoic loc. 29799.

8, 9. Hypotype, USNM 248074 from USGS Mesozoic loc. 26778.

10-12. Ventral and lateral views of hypotype, USNM 248077a from USGS Mesozoic loc. 29420.

13,14 . Hypotype, USNM 248075 from USGS Mesozoic loc. 30403.

15. Lateral view of small hypotype, USNM 248077b from USGS Mesozoic loc. 29420.

17, 18. Laterally crushed hypotypes, USNM 248078 from USGS Mesozoic loc. 29771.

19. Iniskinites cf. I. intermedius (Imlay) (p. 20)

Laterally crushed adult body chamber of specimen, USNM 252654 from USGS Mesozoic loc. 31409.

20-26. Lilloettia stantoni Imlay (p. 18)

20. Hypotype, USNM 248079 from USGS Mesozoic loc. 29798.

21, 22. Lateral and ventral views of immature specimen. Hypotype, USNM 252633 from USGS Mesozoic loc. 28376.

23. Hypotype, USNM 252632 from USGS Mesozoic loc. 28376.

24. Hypotype, USNM 248080 from USGS Mesozoic loc. 29798.

25, 26. Hypotype, USNM 252631 from USGS Mesozoic loc. 28376. 
GEOLOGICAL SURVEY
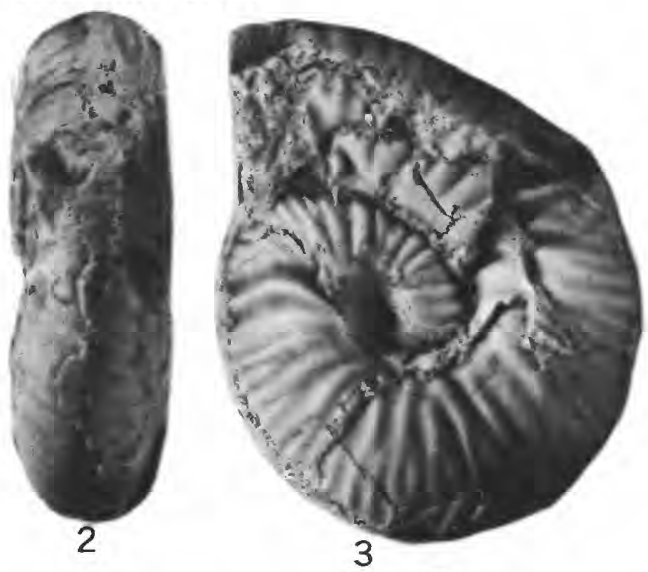

3
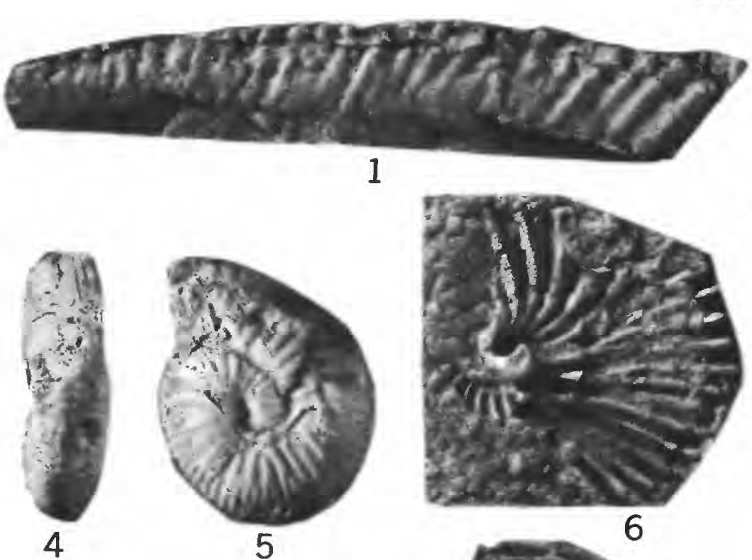

5

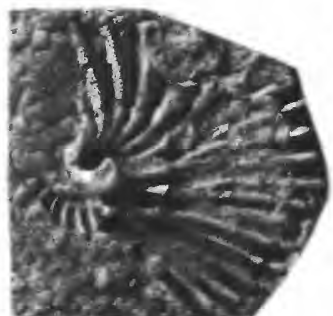

6
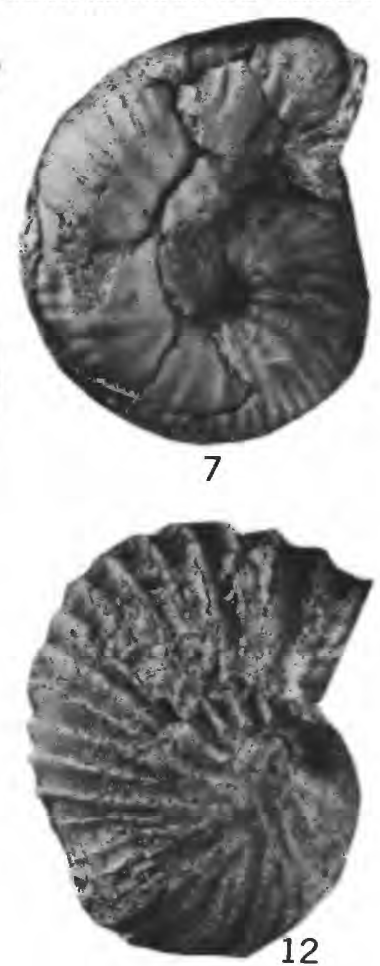
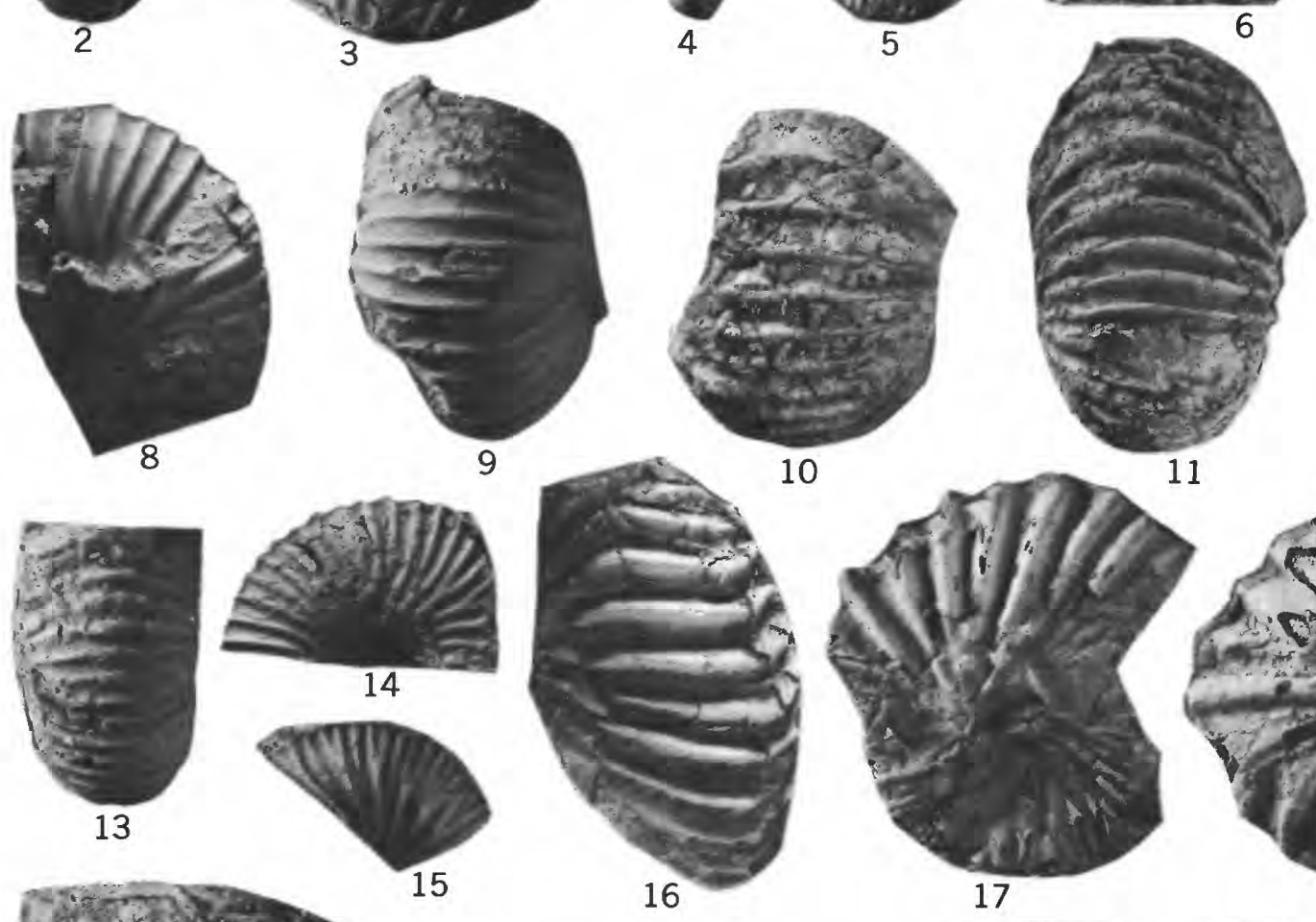

11

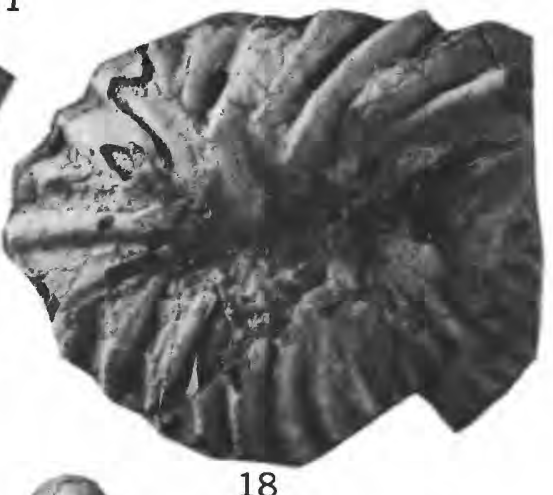

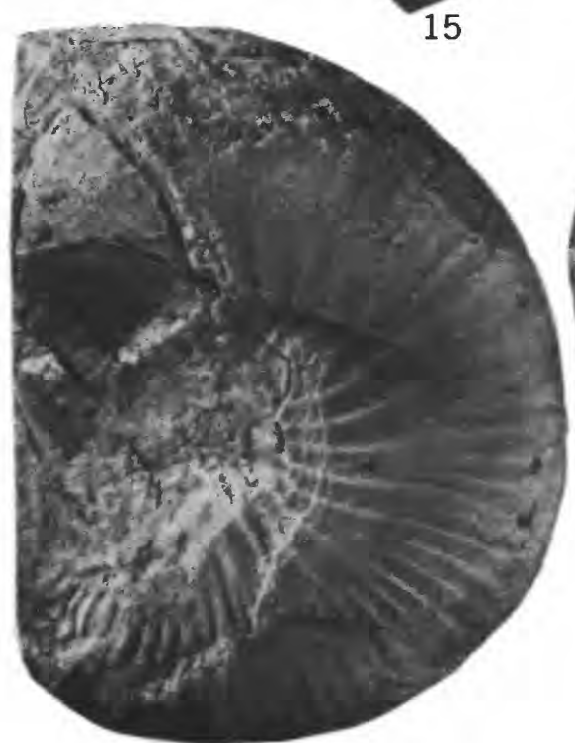

19

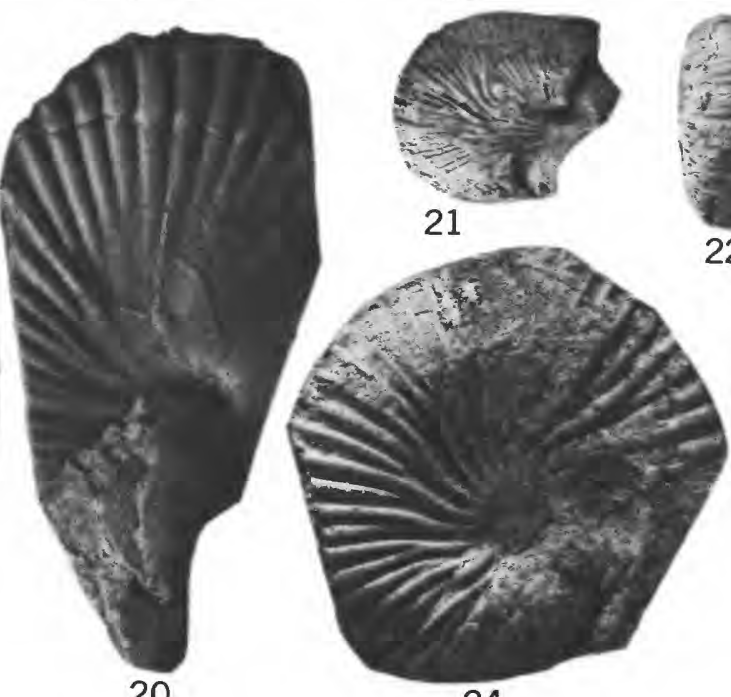

20

24

22
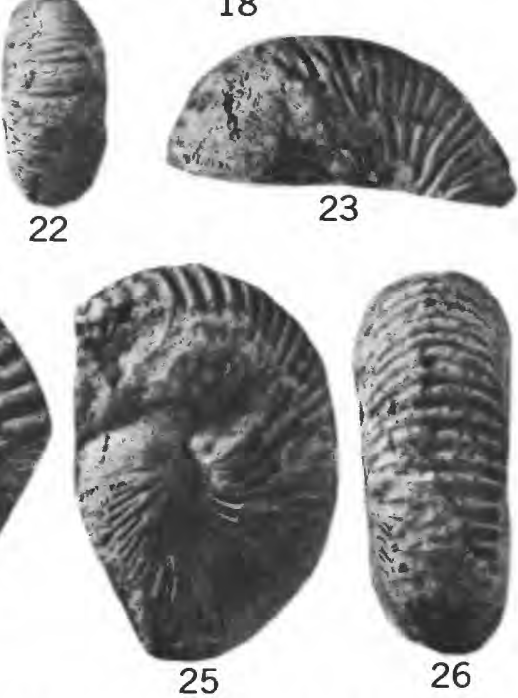

PARAPATOCERAS, BULLATIMORPHITES, XENOCE PHALITES, INISKINITES, AND LILLOETTIA 


\section{PLATE 2}

[All figures are natural size]

FIGURE 1,2. Kepplerites snugharborensis Imlay (p. 18).

Ventral and lateral views of hypotype, USNM 252634 from USGS Mesozoic loc. 30082.

3-8. Pseudocadoceras grewingki (Pompeckj) (p. 20).

3. Hypotype, USNM 252640 from USGS Mesozoic loc. 29421.

4, 5. Hypotype, USNM 252643 from USGS Mesozoic loc. 29421.

6. Hypotype, USNM 252641 from USGS Mesozoic loc. 29421.

7. Hypotype, USNM 252642 from USGS Mesozoic loc. 29421.

8. Hypotype, USNM 252644 from USGS Mesozoic loc. 29421.

9. Kepplerites cf. K. plenus (McLearn) (p. 18).

Figured specimen, USNM 252635 from USGS Mesozoic loc. 31407.

10, 11. Choffatia? sp. (p. 21).

Ventral and lateral views of specimen, USNM 252661 from USGS Mesozoic loc. 29798.

12, 13. Kepplerites sp. (p. 18).

12. Laterally crushed specimen, USNM 252636 from USGS Mesozoic loc. 31454.

13. Rubber imprint of external mold of inner whorls of specimen, USNM 252664 from USGS Mesozoic loc. 31454. 
GEOLOGICAL SURVEY
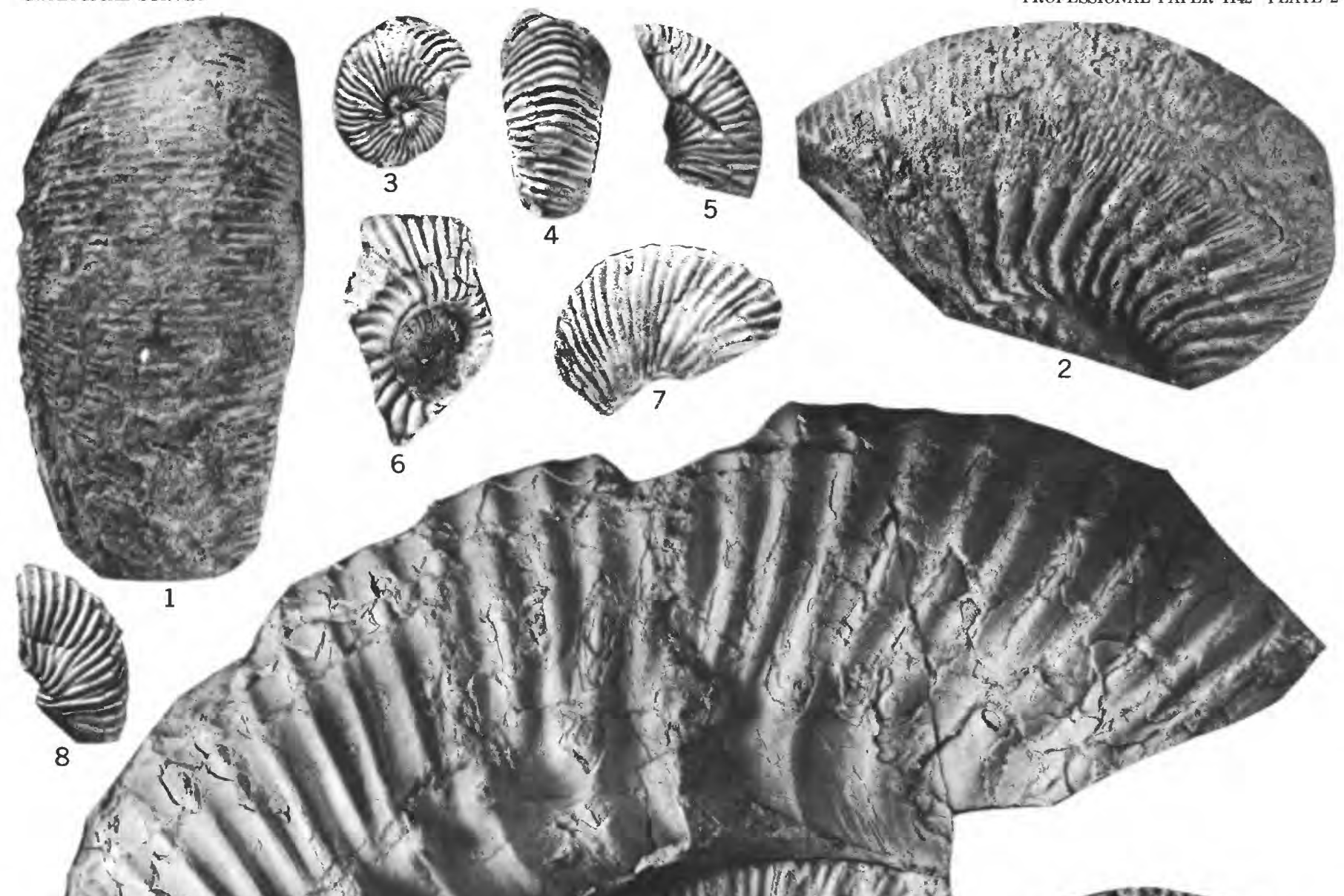

PROFESSIONAL PAPER 1142 PLATE 2
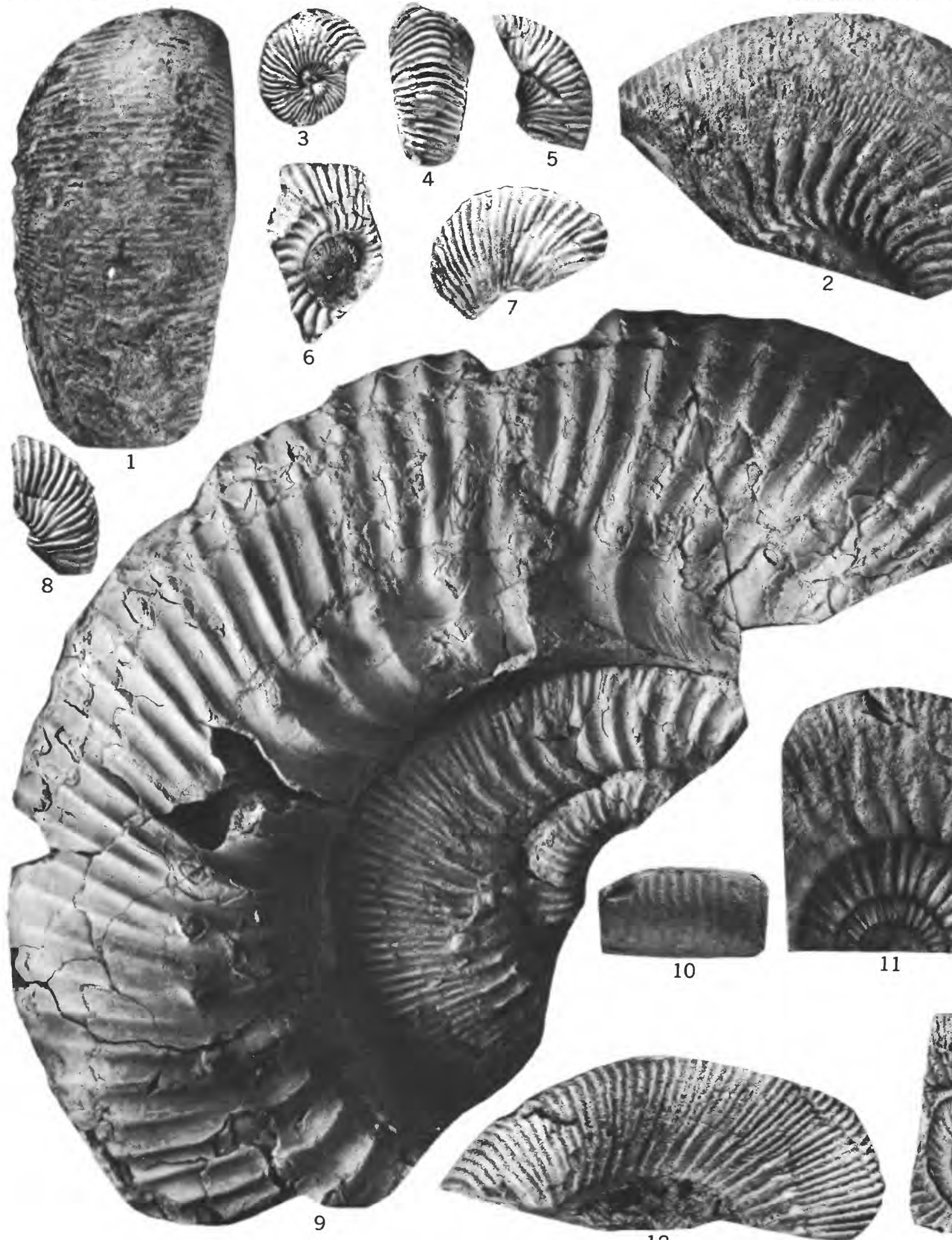

10

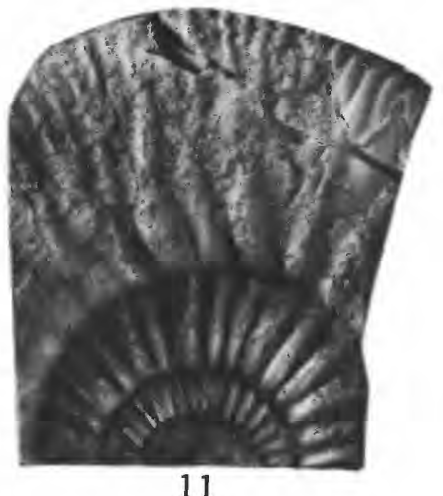

11

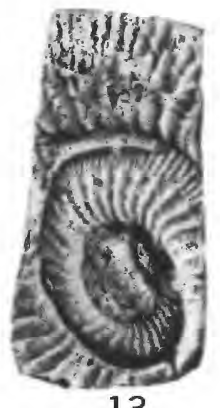

KEPPLERITES, PSEUDOCADOCERAS, AND CHOFFATIA? 


\section{PLATE 3}

[Figures natural size unless otherwise indicated]

Figures 1-4. Torricelliceras spinosus (Imlay) (p. 19).

Holotype, USNM 108138 from USGS Mesozoic loc. 22432 in the Chinitna Formation west of Cook Inlet (Imlay, 1953, p. 99, pl. 53 , figs. 8,11 ).

5. Torricelliceras cf. T. spinosus (Imlay) (p. 19).

Specimen, USNM 252639 from USGS Mesozoic loc. 26778. Bears ribbing similar to that shown in figure 2.

6-10. Torricelliceras izeeensis Imlay, n. sp. (p. 19).

6. Holotype, USNM 252637 from USGS Mesozoic loc. 31408. Shows adult body chamber.

7-10. Paratype, USNM 252638 from USGS Mesozeic loc. 31457. Figures 8-10 $(\times 2)$ show the features of the small innermost whorls. 
GEOLOGICAL SURVEY

PROFESSIONAL PAPER 1142 PLATE
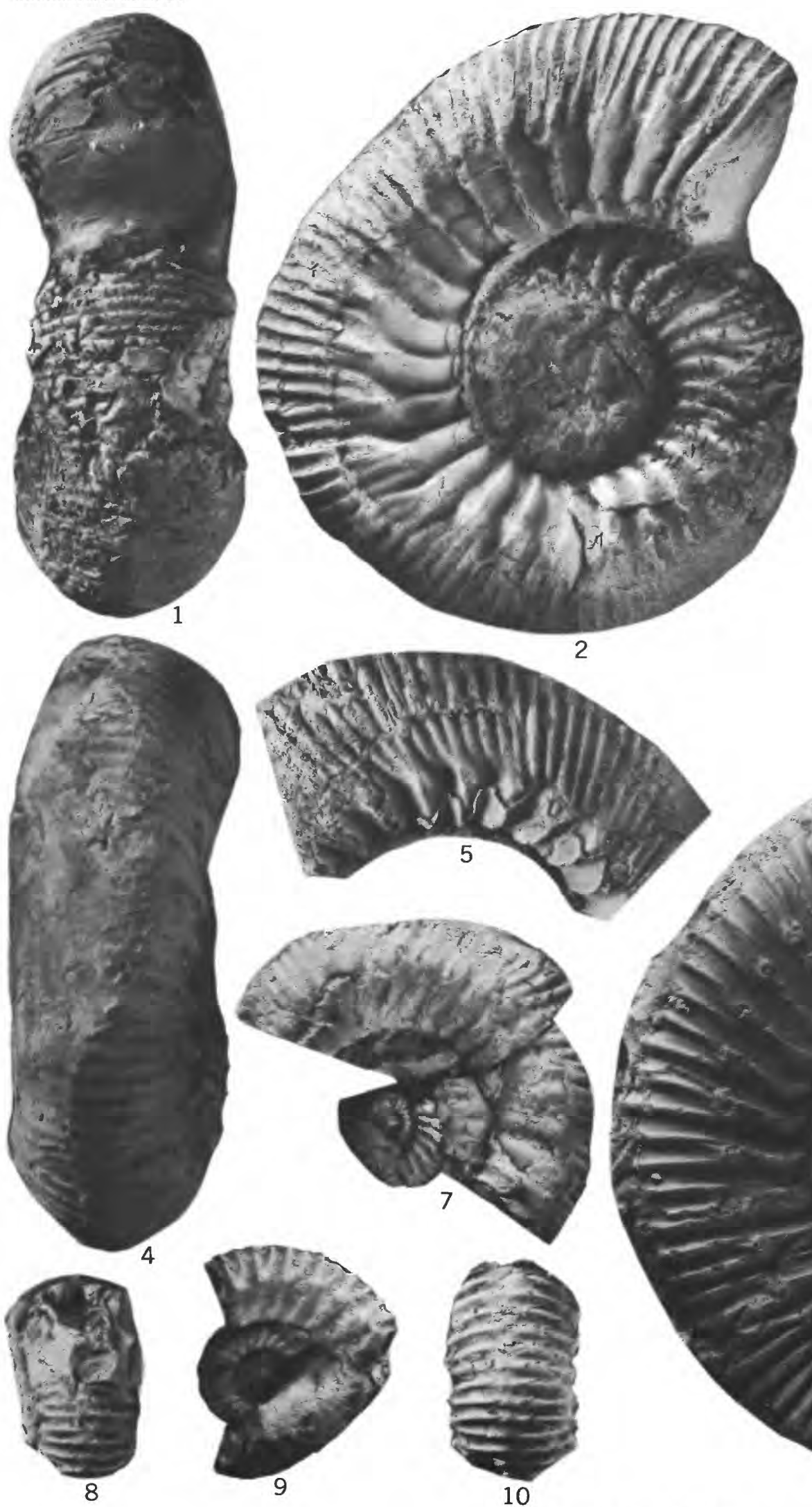

2

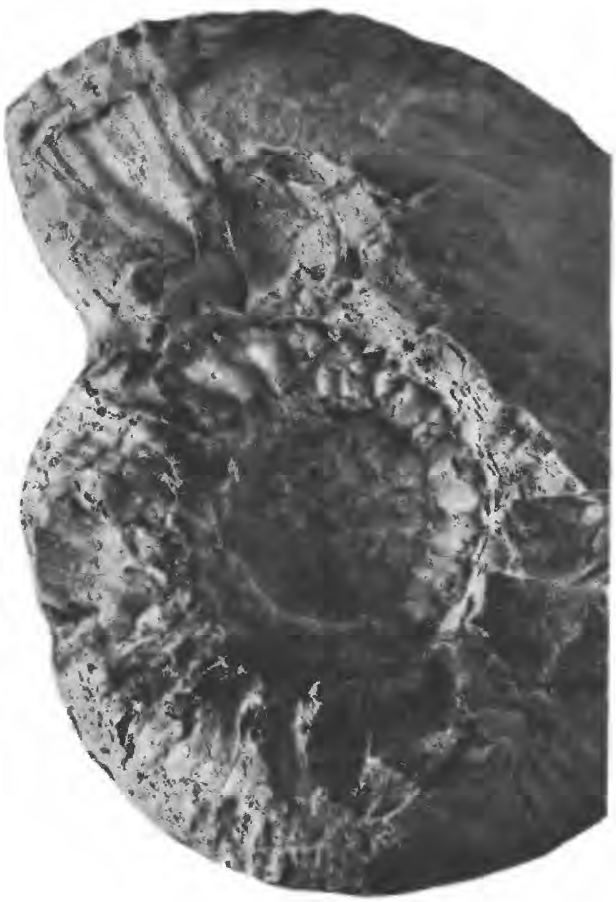

3 


\section{PLATE 4}

[All figures are natural size]

FIGURES 1, 2. Iniskinites martini (Imlay) (p. 20).

Hypotype, USNM 252655 from USGS Mesozoic loc. 30931.

3-14. Iniskinites acuticostatus Imlay, n. sp. (p. 20).

3-5. Intermediate size septate whorl of paratype, USNM 252649 from USGS Mesozoic loc. 31408.

$6,7,10,11$. Small septate whorls assigned respectively to paratypes USNM 252650-252653 from USGS Mesozoic loc. 31408.

8. Paratype, USNM 352646 from USGS Mesozoic loc. 31410 . Note shallow constriction at adoral end of body chamber.

9. Paratype, USNM 252648 from USGS Mesozoic loc. 30401. Well-preserved ribbing occurs on nonseptate part of specimen.

12, 13. Holotype, USNM 252645 from USGS Mesozoic loc. 31410. About three-fifths of outer whorl appears to be nonseptate.

14. Paratype, USNM 252647 from USGS Mesozoic loc. 30401. Well-preserved ribbing occurs on nonseptate part of specimen. 
GEOLOGICAL SURVEY
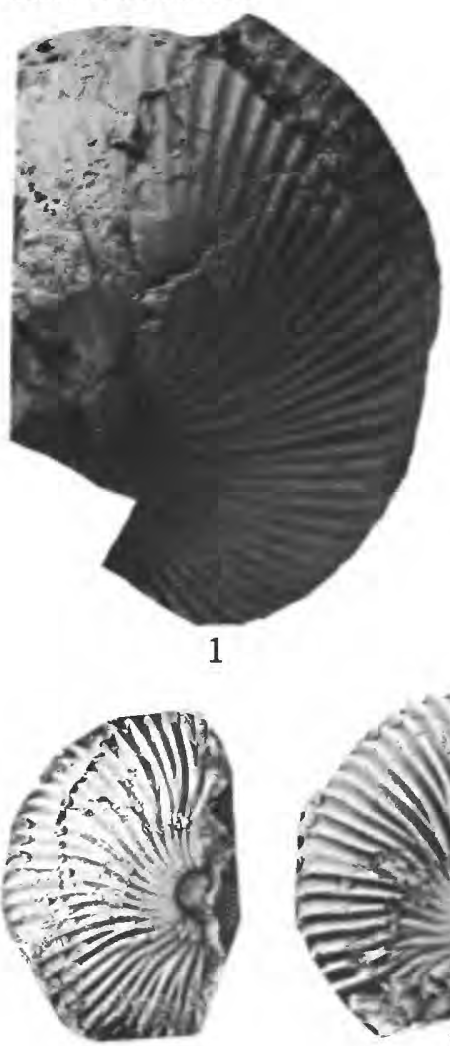

6
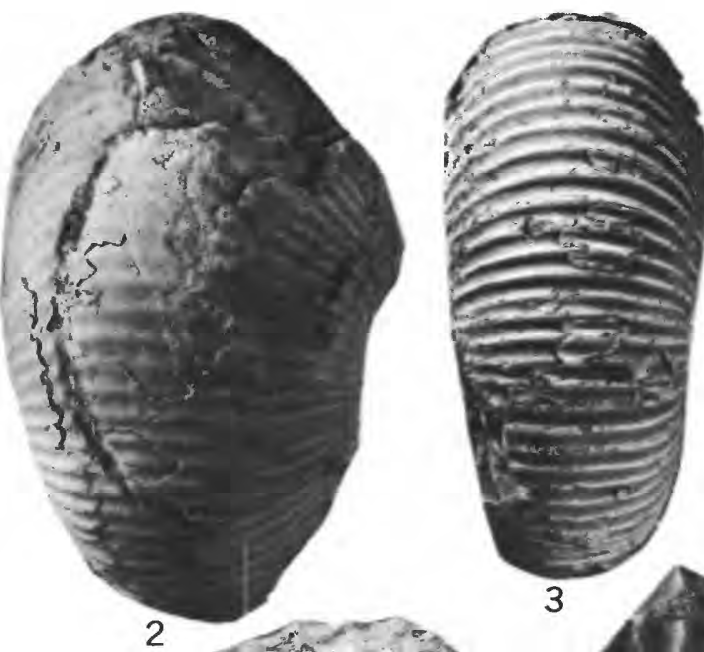

PROFESSIONAL PAPER 1142 PLATE 4
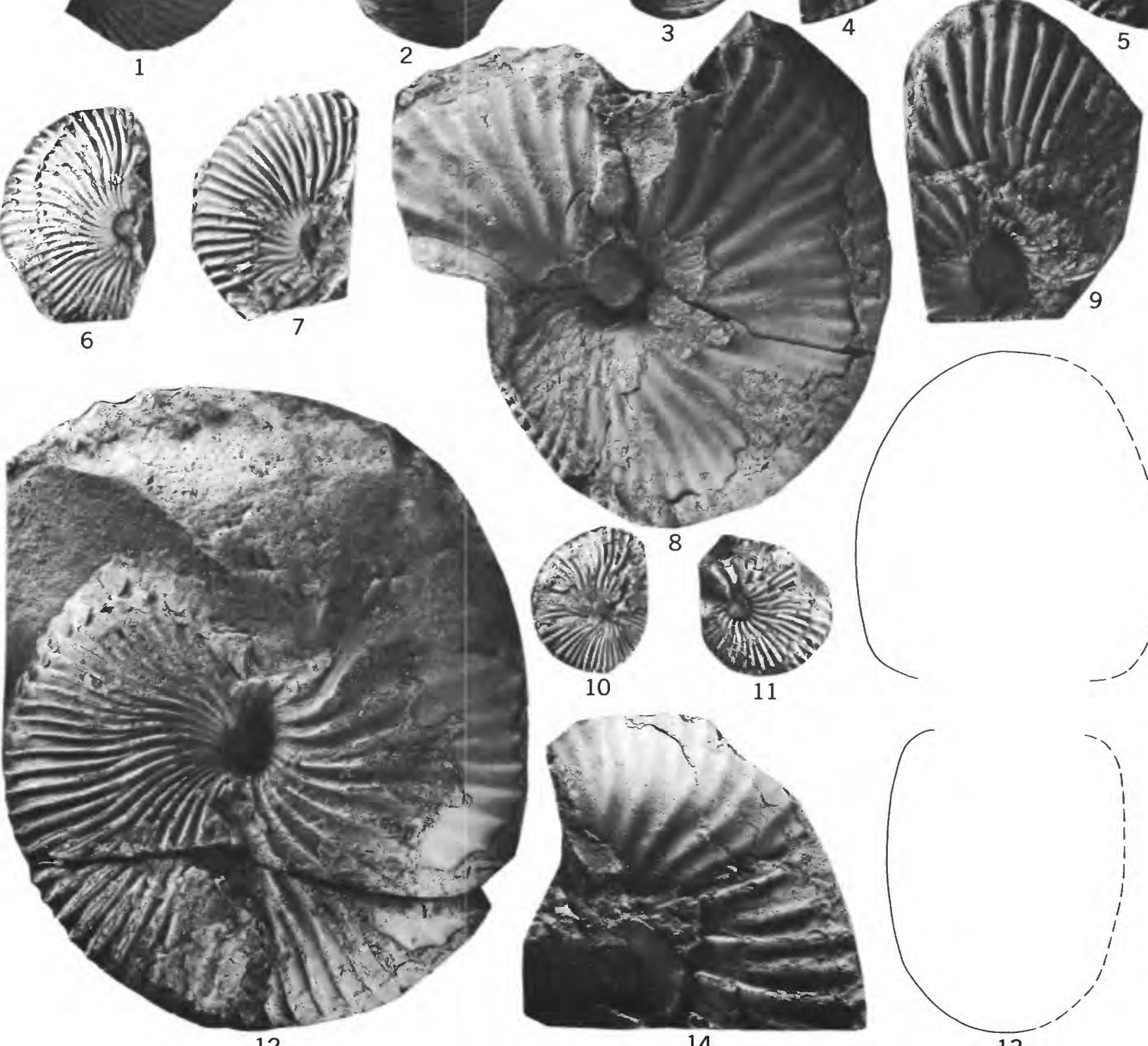

12
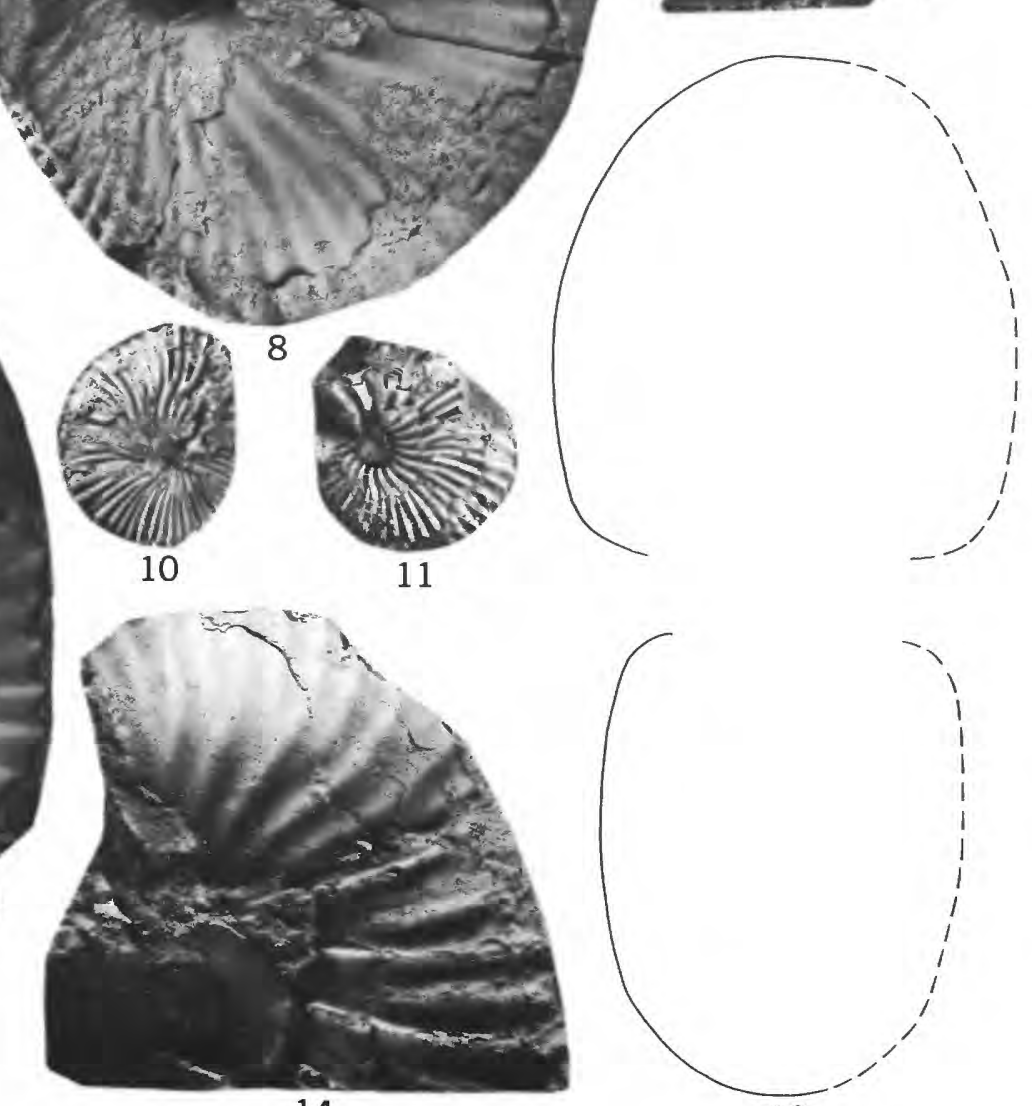

14

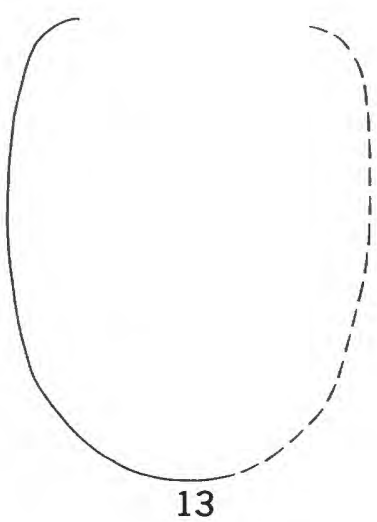

INISKINITES 


\section{PLATE 5}

[Figures natural size unless otherwise indicated]

FIGUREs 1, 4-8. Cobbanites ochocoensis Imlay, n. sp. (p. 21).

1. Paratype, USNM 252659 from USGS Mesozoic loc. 30406.

4. Paratype, USNM 252658 from USGS Mesozoic loc. 30406.

5, 8. Paratype, USNM 252660 from USGS Mesozoic loc. 30408. Laterally compressed fragments of a large specimen show part of the nearly smooth outer whorl and most of the ribbed inner whorls.

6. Paratype, USNM 252657 from USGS Mesozoic loc. 26778.

7. Holotype, USNM 252656 from USGS Mesozoic loc. 30402.

2, 3, 9. Grossouvria sp. (p. 21).

$2(\times 2)$ and 3. Lateral views of specimen USNM 252662 from USGS Mesozoic loc. 29771.

9. Lateral view of specimen, USNM 252663 from USGS Mesozoic loc. 29771. 
GEOLOGICAL SURVEY
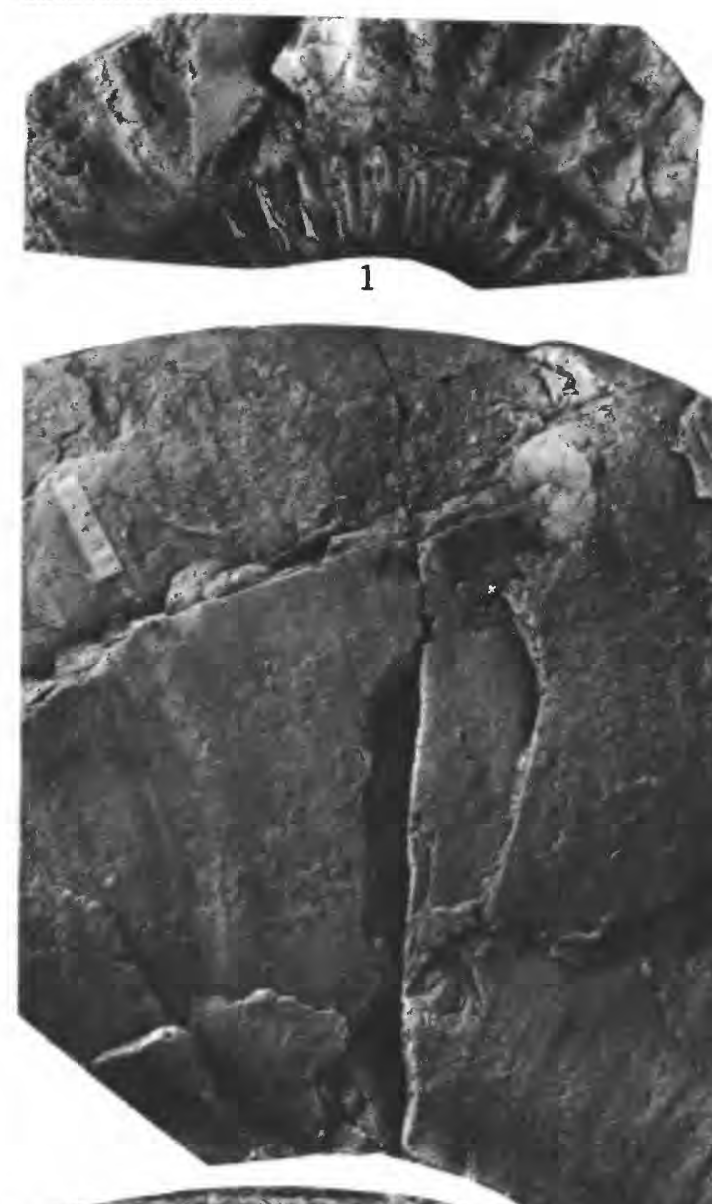

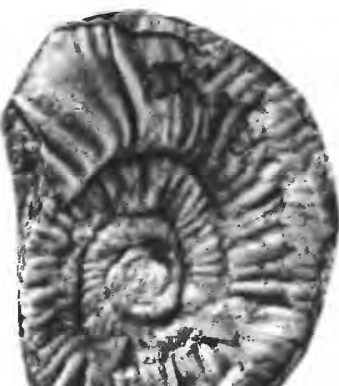

initis

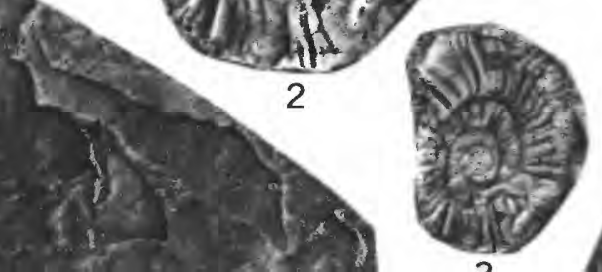

3

3

(

PROFESSIONAL PAPER 1142 PLATE 5
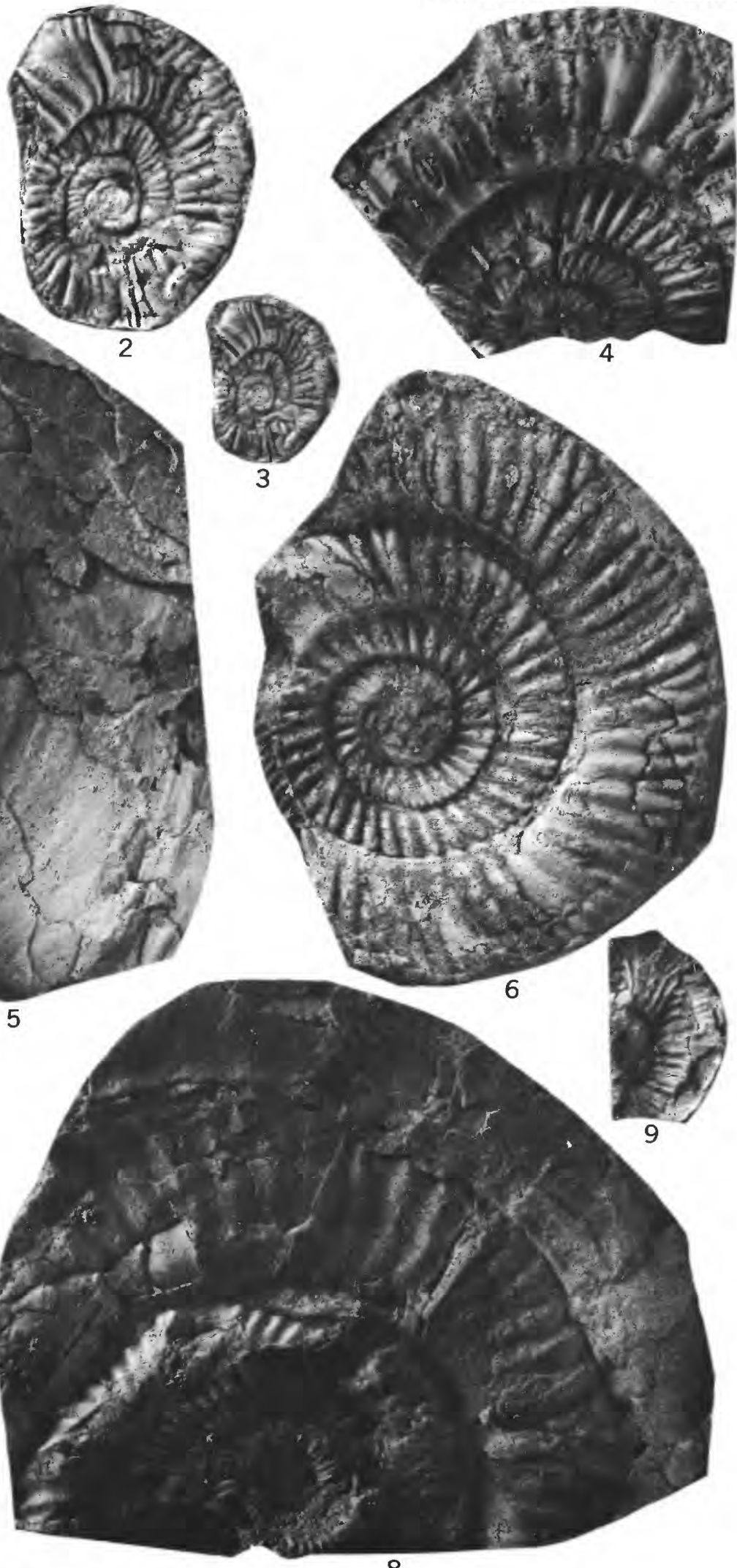

8 
